
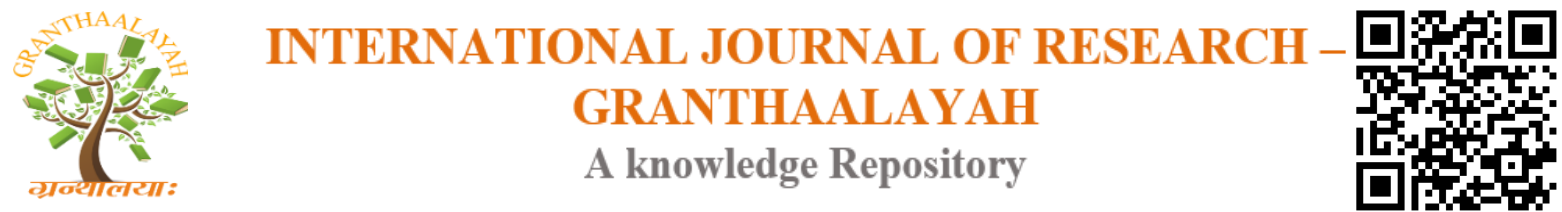

Science

\title{
THE IMPACT OF AGRICULTURAL SYSTEMS IN THE SOIL ORGANIC MATTER CONTENT IN BRAZILIAN CERRADO
}

\author{
Arcângelo Loss *1, Marcos Gervasio Pereira ${ }^{2}$, Sidinei Julio Beutler ${ }^{2}$, Adriano Perin ${ }^{3}$, \\ Marisa de Cassia Piccolo ${ }^{4}$, Shirlei Almeida Assunção ${ }^{2}$, Everaldo Zonta ${ }^{2}$ \\ ${ }^{* 1}$ Federal University of Santa Catarina. Professor at Master's and Doctoral Degree Program in \\ Agroecosystem, Florianopolis, Santa Catarina, Brazil. \\ ${ }^{2}$ Federal Rural University of Rio de Janeiro. Institute of Agronomy. Department of Soil. \\ Laboratory of Soil Genesis and Classification and Soil and Plant Laboratory. Rio de Janeiro, \\ Brazil. \\ ${ }^{3}$ Federal Goiano Institute. Department of Plant Science, Rio Verde Campus, Rio Verde, Goias, \\ Brazil \\ ${ }^{4}$ University of São Paulo. Nutrient Cycle Laboratory, Center for Nuclear Energy in Agriculture, \\ Piracicaba, São Paulo, Brazil
}

\begin{abstract}
Were quantified the plant residues on the soil, total soil organic carbon (TOC) and nitrogen (TN) contents and the different soil organic matte (SOM) fractions and to determine ${ }^{13} \mathrm{C}$ and ${ }^{15} \mathrm{~N}$ isotopic soil composition and plant residues in the crop-livestock integration system (CLIS), pasture and Cerrado areas, in Goias, Brazil. TOC and TN, $\mathrm{C}$ and $\mathrm{N}$ light organic matter content (C-LOM/N$\mathrm{LOM})$; $\mathrm{C}$ and $\mathrm{N}$ of particulate organic matter (C-POM/N-POM); and mineral organic matter $(\mathrm{C}$ MOM/N-MOM) were evaluated. $\delta^{13} \mathrm{C}$ and $\delta^{15} \mathrm{~N}$ of soil and LOM, POM, and MOM fractions, as well as the $\delta^{13} \mathrm{C}$ of plant residues, were also determined. Plant residues from pasture were more enriched with nutrients and C, and CLIS which are richer in N. $\delta^{13} \mathrm{C}$ of pasture and CLIS soils indicated that the $\mathrm{C}$ from the Cerrado vegetation (typically $\mathrm{C}_{3}$ ) was replaced by vegetation with $\mathrm{C}_{4}$ photosynthetic mechanisms. CLIS accumulated more TOC than the pasture, and provided higher $\mathrm{C}-\mathrm{MOM}$ and N-MOM values than pasture, and higher N-LOM levels than pasture and Cerrado. $\delta^{13} \mathrm{C}$ of LOM is associated with more recent origins of carbon. $\delta^{15} \mathrm{~N}$ of POM and soil of the CLIS and pasture indicate greater mineralization of SOM.
\end{abstract}

Keywords: Plant Residues; Particulate Organic Matter; Light Organic Matter; Crop-Livestock Integration System; Urochloa sp.

Cite This Article: Arcângelo Loss, Marcos Gervasio Pereira, Sidinei Julio Beutler, Adriano Perin, Marisa de Cassia Piccolo, Shirlei Almeida Assunção, and Everaldo Zonta. (2019). "THE IMPACT OF AGRICULTURAL SYSTEMS IN THE SOIL ORGANIC MATTER CONTENT IN BRAZILIAN CERRADO.” International Journal of Research - Granthaalayah, 7(8), 220-244. https://doi.org/10.29121/granthaalayah.v7.i8.2019.662. 


\section{Introduction}

The Cerrado biome is the largest savanna region in South America. It is located in the central portion of Brazil and is the second largest biome within the country, with an area of approximately 200 million hectares. The prevailing soils are Oxisols, which are generally clayey, deep, weathered, and range from flat to smooth/wavy (Ratter et al., 2003; IBGE, 2004; Pereira de Castro et al., 2016). As Oxisols have good physical characteristics, much of the Brazilian Cerrado is used for extensive soybean, corn, beans, cotton, and sugarcane plantations (Sano et al., 2008; Loss et al., 2016), being one of the largest cultivated areas in the world (Maia et al., 2013).

Approximately $97.0 \%$ of the state of Goiás (Brazil) is within the Cerrado biome (IBGE, 2004). Also, almost 55.0\% of Goiás is used for human activities (Sano et al., 2008), of which 27.7\% holds agricultural crops, $71.0 \%$ has cultivated pastures, and the remainder is occupied by forest plantation and urban areas. Regarding land use systems commonly used with agricultural crops and pastures, the no-tillage system (NTS) and crop-livestock integration system (CLIS) are the most used, respectively. Both systems have the potential to accumulate carbon in Cerrado soils. In CLIS, the use of forage increases haystack production, especially during the dry season, promoting an efficient development of NTS and the subsequent accumulation of organic matter in the soil (Carvalho et al., 2010; Loss et al., 2012a, 2016; Sant-Ana et al., 2017).

The combination of environmental factors (e.g., high precipitation and high temperatures for most of the year), intrinsic factors of the soil (e.g., the prevalence of 1:1 clay minerals), and factors related to the functional attributes of plant material added to the soil ( $\mathrm{C} / \mathrm{N}$ ratio and lignin content) results in different processes regarding the dynamics of organic matter in the soil (SOM) in the Cerrado biome. Thus, well planned and conducted NTS and CLIS are used to obtain high quality agricultural production and preserve soil system resources. These systems result in better environmental conditions, since observed diversity, paths of nutrient flows, and other common processes in nature promote more conservationist agriculture (Carvalho et al., 2010, Loss et al., 2013, Tivet et al., 2013, Sant-Ana et al., 2017).

In the Cerrado, the continuous use of NTS and CLIS for food production and efficient soil management seems unquestionable. However, further studies are needed to evaluate changes occurring in the soil over time, especially when management system or land use is substituted over time. For example, in the Brazilian Cerrado, many areas that are currently managed using CLIS, were managed only with pastures 30 to 40 years ago, after the original vegetation was removed (Cerrado). After that, pastures were replaced by grain cultivation in conventional soil preparation systems (CPS), with plowing and harrowing. Then, CPS was replaced by NTS with crop rotation and, finally, part of the NTS was conducted in CLIS in the 2000s (Loss et al., 2012a; 2013).

The different chemical and physical fractions of SOM are among the most used parameters to evaluate soil changes resulting from management systems and/or land use. The light organic matter (LOM) is one of these fractions, consisting of a heterogeneous mixture of recent plant residues, small-animal remains, and microorganisms, which can be in different stages of decomposition (Gregorich et al., 1994). The amount and composition of the LOM is reported by several studies as the most sensitive indicator used to characterize the most appropriate soil management forms (Bremer et al., 1995; Leite et al., 2003; Liebig et al., 2004; Koutika et al., 2005; Loss et al., 2012b). 
Higher amounts of LOM observed in NTS areas using cover plants in the Cerrado, may reduce soil phosphorus adsorption (Pereira et al., 2010).

The SOM fractions obtained through particle size fractionation are also widely used to evaluate land use changes. The particulate organic matter (POM) is the fraction corresponding to silt and sand size $(>53 \mu \mathrm{m})$, being the most dynamic and sensitive to soil management. The mineral organic matter (MOM) fraction is smaller than $53 \mu \mathrm{m}$ and is considered an organic material associated with the mineral components of the soil, forming organomineral complexes and showing reduced sensitivity to management. The carbon $(\mathrm{C})$ and nitrogen $(\mathrm{N})$ contents are quantified in the POM and MOM fractions, providing the C-POM and N-POM, and C-MOM and N-MOM, respectively. The $\mathrm{C}$ and $\mathrm{N}$ of POM are derived from plant and hyphae residues that remain in the soil due to physical protection in aggregates, being labile fractions that present higher recycling rates of organic constituents (Golchin et al., 1994). Higher accumulations of C and N are observed in POM fractions in systems with greater aerial and root biomass inputs, thus being more sensitive indicators than total organic $\mathrm{C}$ (TOC) and total $\mathrm{N}(\mathrm{TN})$ regarding the changes imposed by soil management (Loss et al., 2012c, Luce et al., 2013, 2014). Particulate $\mathrm{C}$ and $\mathrm{N}$ fractions, after being mineralized by microorganisms, are important sources of mineral $\mathrm{C}$ and $\mathrm{N}$ in agricultural soils (Luce et al., 2014).

The isotopic methods have greatly contributed to the understanding of the origin of $\mathrm{C}$ and $\mathrm{N}$ in the different fractions of SOM, as well as the overall dynamics of these nutrients in agricultural systems. These elements present chemically stable and radioactive forms. $\mathrm{C}$ and $\mathrm{N}$ are important in SOM studies in both stable $\left({ }^{12} \mathrm{C}\right.$ and ${ }^{13} \mathrm{C}$, and ${ }^{14} \mathrm{~N}$ and $\left.{ }^{15} \mathrm{~N}\right)$ and unstable $\left({ }^{14} \mathrm{C}\right.$ and $\left.{ }^{13} \mathrm{~N}\right)$ forms (Marin-Spiotta et al., 2009; Cook et al., 2014; Loss et al., 2014). The modification of the Cerrado biome by cutting down and burning natural vegetation in different management systems usually reduces SOM levels (Bernoux et al., 2004; Loss et al., 2016), changing the $\mathrm{C}$ and $\mathrm{N}$ distributions, as well as the $\delta^{13} \mathrm{C}$ and $\delta^{15} \mathrm{~N}$ natural abundance values (Bustamante et al., 2004; Costa Junior et al., 2011; Loss et al., 2014). Loss et al., (2014) evaluated the natural abundance of $\delta^{13} \mathrm{C}$ and $\delta^{15} \mathrm{~N}$ in soil profiles of areas with different soil use systems in the Cerrado of Goiás and observed that the replacement of the original Cerradão vegetation by NTS and CLIS systems changed the $\delta^{13} \mathrm{C}$ signal. Specifically, after 17 years of cultivation, the incorporation of $\mathrm{C}$ from grasses in the areas produced an increase of the $\delta^{13} \mathrm{C}$ signal. The authors also reported that the isotopic analysis of $\delta^{15} \mathrm{~N}$ indicated higher SOM mineralization with increasing soil depth, and higher rates in cultivated areas.

In the state of Goiás (Brazil), 70\% of the land is used with pastures (Sano et al., 2008). Pasture areas, if well managed, have great potential for SOM addition and may even surpass the values of native vegetation areas (Silva et al., 2004). Therefore, they represent good areas for comparing SOM management under different land use systems. Some authors have studied NTS with the inclusion of pastures (mainly forages of the genus Urochloa) in crop and animal component rotation systems, characterizing CLIS (Carvalho et al., 2010; Loss et al., 2012, 2013, Sant-Ana et al., 2017). Nevertheless, long-term studies with CLIS are still necessary to provide technicalscientific foundations for the advancement of knowledge and research on the dynamics of different SOM fractions in this system, ultimately seeking soil conservation. The objectives of this study were: (a) to quantify plant residues on the soil; (b) to quantify TOC and TN soil contents and 
different SOM fractions; and (c) to determine the isotopic composition of ${ }^{13} \mathrm{C}$ and ${ }^{15} \mathrm{~N}$ in soil and plant residues in CLIS, pasture, and Cerrado areas, in the state of Goiás (Brazil).

\section{Material and Methods}

\subsection{Location and History of The Areas}

The study was conducted in the municipality of Montividiu - GO, at Fazenda Vargem Grande, which belong to the company Agropecuária Peeters (macroregion of Rio Verde - GO; Figure 1).

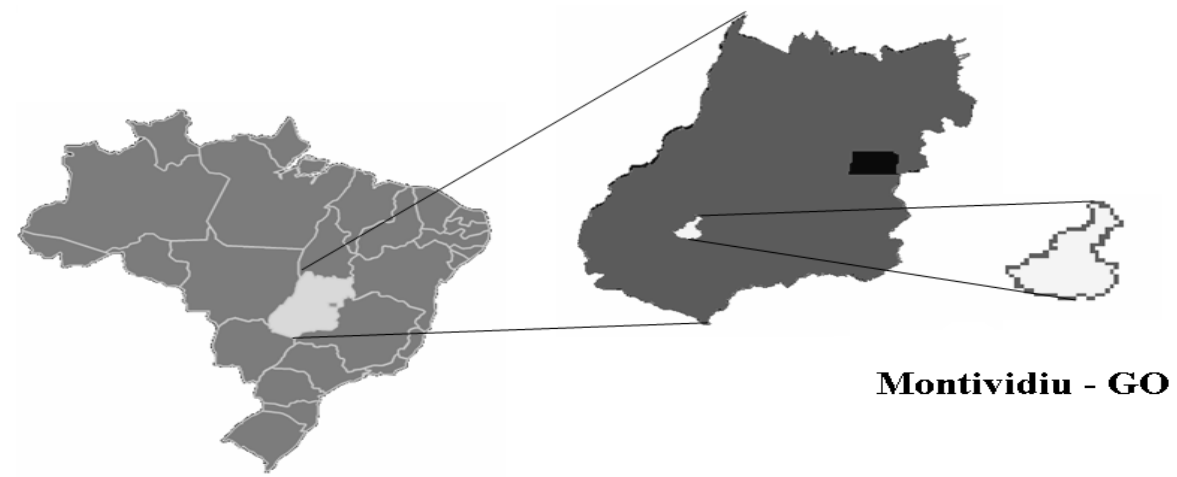

Figure 1: Location of the municipality of Montividiu (GO) within the Brazilian geographical context.

Plant residues and soil samples were collected in three different areas in 2010, namely, a crop area (S $17^{\circ} 19^{\prime} 35.5^{\prime \prime}$ and $\mathrm{W} 51^{\circ} 29^{\prime} 29.7^{\prime \prime}$, altitude of $961 \mathrm{~m}$ ) under the no-tillage system and CLIS with 13 years of implantation, a pasture area with Urochloa decumbens Stapf (S 17 $22^{\prime} 04.5^{\prime \prime}$ and W 51 29' 52.7"; altitude of $946 \mathrm{~m}$ ) and 15 years of implantation, and a native Cerrado area (S $17^{\circ}$ $22^{\prime} 12.2^{\prime \prime}$ and W 51 29'49.8'; altitude of $942 \mathrm{~m}$ ), representing the original conditions of the soil. The soils of the study areas are the same, rated as Dystrophic Oxisols with clayey texture. The soil fertility attributes of the studied areas are shown in Table 1.

Table 1: $\mathrm{pH}$ values, nutrients, $\mathrm{H}+\mathrm{Al}$, and remaining phosphorus ( $\mathrm{P}$ rem) in different soil management systems in the Cerrado, Montividiu, GO, Brazil.

\begin{tabular}{|c|c|c|c|c|c|c|c|c|}
\hline \multirow{3}{*}{$\begin{array}{c}\text { Evaluated } \\
\text { systems }\end{array}$} & \multirow{2}{*}{$\begin{array}{c}\text { pH } \\
(\mathbf{H} 20)\end{array}$} & $\mathbf{C a}$ & Mg & $\mathbf{K}$ & Al & $\mathbf{H}+\mathbf{A l}$ & Pava & Prem \\
\hline & & \multicolumn{5}{|c|}{ 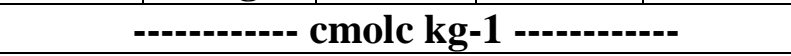 } & \multicolumn{2}{|c|}{---mg kg-1--- } \\
\hline & \multicolumn{8}{|c|}{$0-5 \mathrm{~cm}$} \\
\hline Pasture & 4.97 & 2.94 & 5.20 & 0.12 & 0.00 & 8.29 & 2 & 24.28 \\
\hline CLIS & 5.65 & 2.52 & 7.50 & 0.16 & 0.00 & 6.76 & 8 & 25.66 \\
\hline \multirow[t]{2}{*}{ Cerrado } & 4.16 & 3.08 & 5.30 & 0.13 & 0.41 & 15.09 & 2 & 20.89 \\
\hline & \multicolumn{8}{|c|}{$5-10 \mathrm{~cm}$} \\
\hline Pasture & 4.77 & 2.50 & 3.56 & 0.07 & 0.00 & 9.11 & 4 & 21.98 \\
\hline CLIS & 5.36 & 2.40 & 5.58 & 0.08 & 0.00 & 7.51 & 10 & 25.50 \\
\hline Cerrado & 3.93 & 0.68 & 1.06 & 0.08 & 0.41 & 11.97 & 1 & 19.87 \\
\hline
\end{tabular}

CLIS: Crop-livestock integration system. None of the areas presented detectable sodium (Na) levels; Ca: exchangeable calcium; $\mathrm{Mg}$ : exchangeable magnesium; $\mathrm{K}$ : exchangeable potassium; $\mathrm{H}+\mathrm{Al}$ : potential acidity; $\mathrm{Al}$ : exchangeable aluminum; Pava: available phosphorus; Prem: remaining phosphorus. 
The mean annual precipitation of the Rio Verde and Montividiu region is $1700 \mathrm{~mm}$ and the mean annual temperature is $22.5^{\circ} \mathrm{C}$, with the existence of rainy and dry seasons. The Figure 2 shows the climatic pattern in 2009 (year before collection) and 2010 (samples were collected in April 2010). This information indicates that the period of 2009 to 2010 had an above average precipitation volume, especially from December to April.

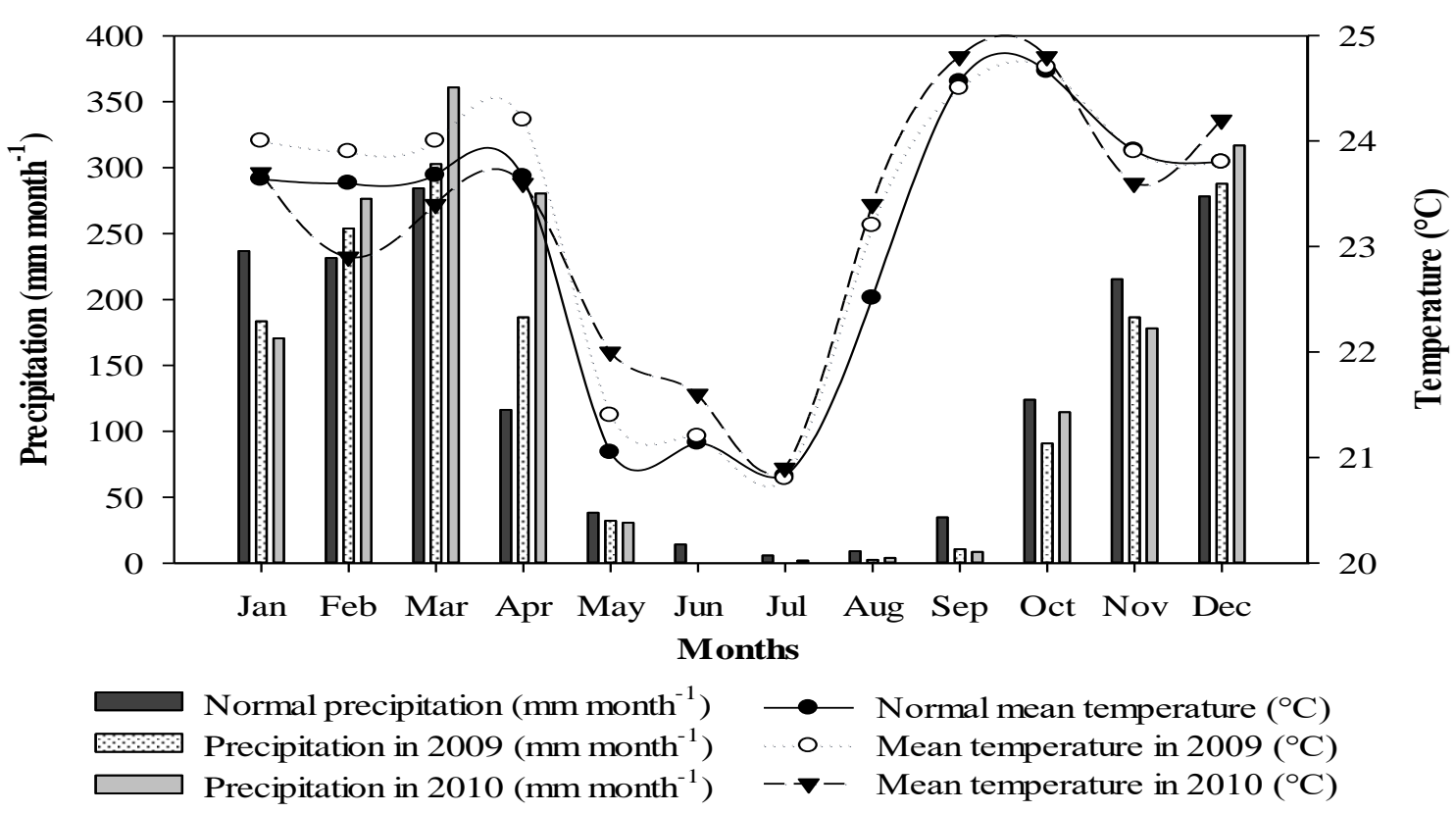

Figure 2: Climatic normals of rainfall (series from 1997 to 2010) and average temperature (series from 2003 to 2010), and rainfall and average temperature of the years 2009 and 2010 in the region of Montividiu-GO, Brazil. (Source: FESURV Meteorological Station - University of Rio Verde - GO. Latitude: $17^{\circ} 48^{\prime} \mathrm{S}$; Longitude: $50^{\circ} 55^{\prime} \mathrm{W}$, Rio Verde - GO).

The area with CLIS has been used for production for 26 years (since the 1984/85 crop harvest) and was previously composed of native vegetation (Cerradão). A palisade grass (Urochloa decumbens Stapf) pasture was introduced during early exploitation for beef cattle breeding and remained for a 10-year period (1984/85 to 1993/94). After this period, the area was exploited by grain crops for 16 years (1994/95 to 2009/10). The conventional tillage system (CTS) was used in the first 3 years after grazing (1994/95 to 1996/97), when CLIS was implemented in the area (1997/98 to 2009/10), amounting to 13 years of use.

As previously described, the area was exploited for cropping for 16 years (1994/95 to 2009/10). During the first 13 years (1994/95 to 2006/07) after that period, the area was always used with crop rotation, cultivating soybean in summer (between October and February) and corn in winter (between February and June). Urochloa ruziziensis (Germain et Evrard) was sown along with winter corn to increase haystack production, which was used for grazing beef cattle in the dry period (June to September), thus, following a CLIS (Figure 3). 


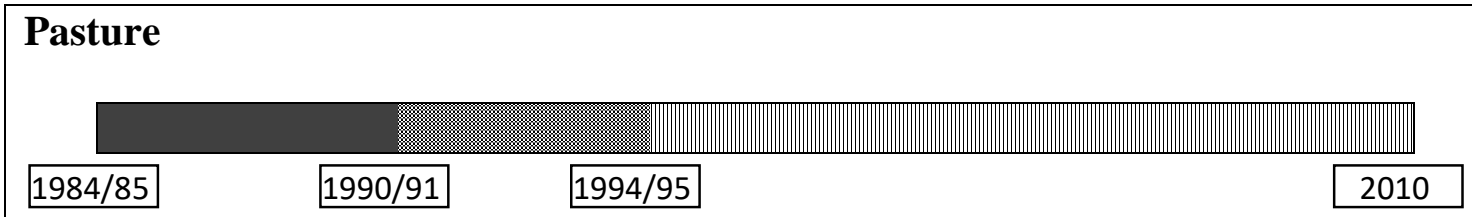

\section{CLIS}
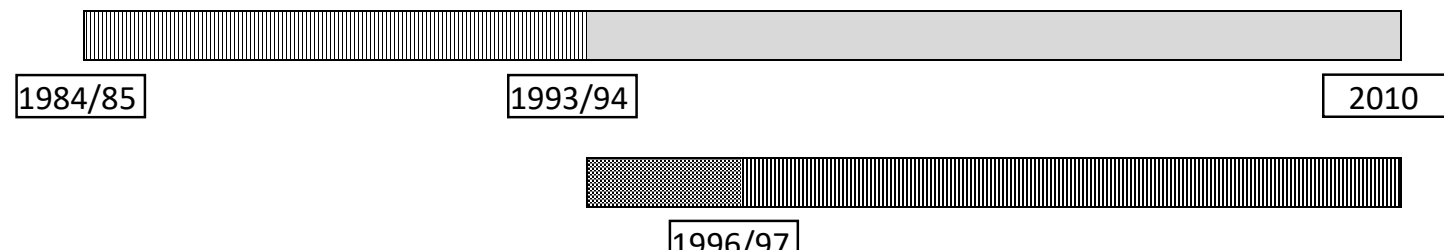

$1996 / 97$

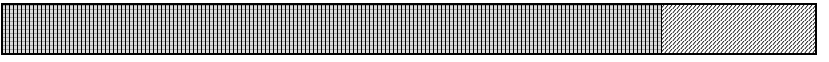

$2006 / 07$

\section{Cerrado}
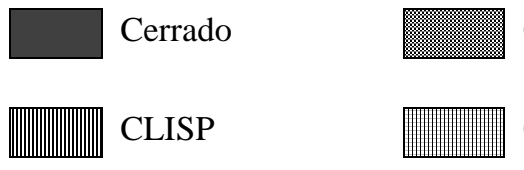

CTS

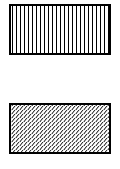

Pasture

Crops

Crop rotation soybean/corn/ + brachiaria

Figure 3: Land use history in the different areas evaluated in Montividiu, GO, Brazil. CLIS: crop-livestock integration; CTS: conventional tillage system.

New crops were introduced in the rotation system during the 2007/2008 harvest, with cotton being cultivated between November 2007 and August 2008. Soybean was grown during the 2008/2009 harvest. Beans were grown between September and December during the 2009/2010 harvest, followed by cotton (December 2009 to August 2010). The samples were collected when cotton was being cultivated (April 2010). It is noteworthy that winter corn crops were always cultivated along with Brachiaria.

The pasture area is composed exclusively of Urochloa decumbens Stapf. and was established 15 years ago (since 1995). The area was previously occupied by native vegetation (Cerradão). In 1990/91, rice and soybean started to be cropped in conventional tillage, enduring a period of 5 years (1990/91 to 1994/95 harvests). During this period, the area received the last applications of mineral fertilizers and limestone. Fertilizers and correctives were no longer used in the area after 
pasture implantation. Animal stocking of the pasture was approximately 1.4 animal unit (AU) ha

${ }^{1}$ during grazing, always avoiding animal overcrowding.

The Cerrado area was adopted as a comparative area, being a parameter for the discussion of the values observed in the anthropized areas. The crop fertilization management in CLIS has been the same throughout the years. However, each crop receives a specific dosage. Thus, the dosages and formulations of each crop are:

1) Soybean: $360 \mathrm{~kg} \mathrm{ha}^{-1}$ of $02: 20: 18+20 \mathrm{~g} \mathrm{ha}^{-1}$ of $\mathrm{Mo}+6 \mathrm{~g} \mathrm{ha}^{-1}$ of Co (sowing);

2) Corn + Brachiaria: $320 \mathrm{~kg} \mathrm{ha}^{-1}$ of 08:20:20 + 0.6\% Zn (sowing) $+60 \mathrm{~kg} \mathrm{ha}^{-1}$ of nitrogen approximately 40 days after the corn emergence;

3) Bean: $400 \mathrm{~kg} \mathrm{ha}^{-1}$ of 05:20:10 (sowing) $+40 \mathrm{~kg} \mathrm{ha}^{-1}$ of nitrogen at approximately 28 days after emergence;

4) Cotton: $550 \mathrm{~kg} \mathrm{ha}^{-1}$ of 10:30:10 (sowing) + 200 $\mathrm{kg} \mathrm{ha}^{-1}$ of 20:00:20 at approximately 40 days after emergence.

The last liming was performed in 2007 , by applying $3.0 \mathrm{Mg} \mathrm{ha}^{-1}$ of dolomitic limestone with $82 \%$ RPTN to increase base saturation to $60 \%$. The mean productivities observed in CLIS until the last harvest were as follows: soybean, 3,840 $\mathrm{kg} \mathrm{ha}^{-1}$; winter corn intercropped with Brachiaria, 5,922 $\mathrm{kg} \mathrm{ha}^{-1}$; beans, 2,520 $\mathrm{kg} \mathrm{ha}^{-1}$; and cotton: 312.0 arrobas ha-1.

Beef cattle are grazed after corn harvest, taking advantage of corn and Brachiaria pasture residues. Cattle stay in the area from July to September, i.e., approximately 70 days. Animal stocking during this period is approximately 8.0 $\mathrm{AU} \mathrm{ha}^{-1}$.

\subsection{Sample Collection and Preparation}

All soil and plant residues samples were collected in April 2010. For chemical analyses of total organic carbon (TOC) and total nitrogen (TN), the samples were collected at depths of $0-5 \mathrm{~cm}, 5-$ $10 \mathrm{~cm}, 10-20 \mathrm{~cm}$, and 20-40 cm with 5 composite samples for each depth, being each composite sample formed from 3 simple ones. For the particle size fraction analyses of SOM and light organic matter (LOM), only the samples from the 0-5 and 5-10 cm layers were used. To determine the $\delta^{13} \mathrm{C}$, three trenches were opened in each area up to $100 \mathrm{~cm}$ deep. Samples were collected at layers 0-5, 5-10, 10-20, 20-30, 30-40, 40-60, 60-80, and 80-100 cm. All soil samples were air-dried, stripped, and passed through a $2.00 \mathrm{~mm}$ mesh to obtain air-dried fine soil (ADFS). The chemical and physical analyses were performed using ADFS.

The plant litter in the Cerrado area and the plant residues in the pasture and CLIS areas were collected using a metal square $\left(0.50 \times 0.50 \mathrm{~m} ; 0.25 \mathrm{~m}^{2}\right)$, with 5 replicates. The plant mass collected in the area of the square was taken to the laboratory and dried at $65{ }^{\circ} \mathrm{C}$ for $72 \mathrm{~h}$ in a forced circulation air oven. After dried, the samples were weighed for dry weight estimation $\left(\mathrm{Mg} \mathrm{ha}^{-1}\right)$. The samples were subsequently ground and sulfuric digestion was carried out for nitrogen $(\mathrm{N})$, phosphorus $(\mathrm{P})$, potassium $(\mathrm{K})$, calcium $(\mathrm{Ca})$, and magnesium $(\mathrm{Mg})$ determination (Tedesco et al., 1995). 


\subsection{Laboratory Analysis}

\section{Carbon, Nitrogen, And Isotopic ${ }^{13} \mathrm{C} /{ }^{12} \mathrm{C}$ and ${ }^{15} \mathrm{~N} /{ }^{14} \mathrm{~N}$ Variation of Soil and Plant Residues}

The soil and plant residues samples were previously macerated in a porcelain mortar and passed through a sieve with a 100 -mesh opening $(150 \mu \mathrm{m})$. The TOC, TN, and isotopic ${ }^{13} \mathrm{C} /{ }^{12} \mathrm{C}$ and ${ }^{15} \mathrm{~N} /{ }^{14} \mathrm{~N}$ ratios were determined in this material $\left({ }^{15} \mathrm{~N} /{ }^{14} \mathrm{~N}\right.$ ratio was determined only for SOM fractions). These procedures were performed using an elemental autoanalyzer coupled to a "Carlo Erba/Delta Plus" mass spectrometer. The results of the isotopic variation of carbon were expressed as $\delta^{13} \mathrm{C}(\%)$ in relation to the international standard PDB (Pee Dee Belemnite). For nitrogen, the results were expressed as $\delta^{15} \mathrm{~N}(\%)$ in relation to atmospheric air $(0.3663 \%)$.

\section{Light Organic Matter in Water (LOM)}

Fifty grams of ADFS were weighed and put in a $250 \mathrm{~mL}$ beaker, to which $100 \mathrm{~mL}$ of $0.1 \mathrm{~mol} \mathrm{~L}^{-1}$ $\mathrm{NaOH}$ solution was added. The beaker was allowed to stand for $16 \mathrm{~h}$. After that, the suspension was shaken with a glass rod and all material passed through a $0.25 \mathrm{~mm}$ sieve, eliminating the whole clay and silt fraction (Anderson and Ingram, 1989). Then, the material retained in the sieve (LOM and sand) was quantitatively transferred to the beaker and the volume was filled with water. All the floated material was carefully passed through a $0.25 \mathrm{~mm}$ sieve, in order to separate the LOM from the sand fraction. Then, water was again added to the beaker, which was shaken manually to resuspend the remaining LOM. The material was slowly poured into a $0.25 \mathrm{~mm}$ sieve. This procedure was repeated until all the material that floated with the stirring in water was removed. The material that was retained in the sieve (LOM) was transferred to aluminum containers (previously weighed in a precision scale of $0.0001 \mathrm{~g}$ ) and taken to a drying oven at $65{ }^{\circ} \mathrm{C}$ until reaching a constant weight $(72 \mathrm{~h})$. The whole set was weighed. Later, the LOM mass was obtained, and the $\mathrm{C}$ and $\mathrm{N}$ contents were determined in this material by the dry combustion method in a $\mathrm{C}$ and $\mathrm{N}$ autoanalyzer at $900{ }^{\circ} \mathrm{C}\left(\mathrm{CHN}-600\right.$ Carlo Erba EA-1110, Italy). The $\delta^{13} \mathrm{C}(\%)$ and $\delta^{15} \mathrm{~N}(\%)$ of the LOM were also determined as described above. With the LOM weight and $\mathrm{C}$ and $\mathrm{N}$ content data, a correction was made for each element as follows:

\section{Corrected C content of the LOM $\left(\mathrm{g} \mathrm{kg}^{-1}\right) \times$ LOM in soil $\left(\mathrm{g} \mathrm{kg}^{-1}\right) / 100$}

The procedure was carried out in the same way for nitrogen, only replacing the carbon values with those of nitrogen. After correction, the carbon and nitrogen values for LOM were obtained.

\section{Particle Size Fractionation of SOM}

Twenty grams of ADFS were weighed, $60 \mathrm{ml}$ of sodium hexametaphosphate solution $\left(5 \mathrm{~g} \mathrm{~L}^{-1}\right)$ were added, and the mix was stirred for $15 \mathrm{~h}$ in a horizontal shaker (Cambardella and Elliot, 1992). After stirring, the suspension was passed through a $53 \mu \mathrm{m}$ sieve with the aid of a jet of water to remove all the clay and silt. The material retained in the sieve, consisting of the particulate organic matter (POM) associated with the sand fraction, was oven dried at $60{ }^{\circ} \mathrm{C}$ and its mass was quantified. Then, it was macerated in a porcelain mortar and analyzed for TOC and TN contents in the autoanalyzer at $900{ }^{\circ} \mathrm{C}\left(\mathrm{CHN}-600\right.$ Carlo-Erba EA-1110, Italy). The $\delta^{13} \mathrm{C}(\%)$ and $\delta^{15} \mathrm{~N}(\%)$ of POM were also determined as described above. The material that passed through the $53 \mu \mathrm{m}$ sieve consisted of organic matter associated with minerals (MOM) of the silt and clay fractions. Finally, the difference between TOC/TN and $\mathrm{C}$ and $\mathrm{N}$ of the POM contents were obtained and a 
weight correction was performed. After analyzing the TOC and TN contents in the POM, a calculation was made with the percentage of material retained in the $53 \mu \mathrm{m}$ sieve as follows:

Corrected C content of the POM $\left(\mathrm{g} \mathrm{kg}^{-1}\right)=\mathrm{C}$ of POM $\left(\mathrm{g} \mathrm{kg}^{-1}\right) / 100$

The procedure was carried out in the same way for nitrogen, only replacing the carbon values with nitrogen values. After correcting the $\mathrm{C}$ and $\mathrm{N}$ contents of the POM, the $\mathrm{C}$ and $\mathrm{N}$ of the MOM were calculated as the difference between the soil TOC and POM values, and total soil $\mathrm{N}$ and $\mathrm{N}$ of the POM for carbon and nitrogen, respectively.

After correcting the carbon and nitrogen values of the POM and LOM, a new correction was made for the physical particle size fraction of the SOM as follows:

$$
\begin{gathered}
{[\text { corrected C }- \text { POM }(\mathrm{g} \mathrm{kg}-1)]-[\text { corrected C }- \text { LOM }(\mathrm{g} \mathrm{kg}-1)]} \\
=\text { adjusted C }- \text { POM }(\mathrm{g} \mathrm{kg}-1)
\end{gathered}
$$

At the end, three physical fractions of the SOM were obtained:

1) C-LOM: carbon of light organic matter in water;

2) C-POM: carbon of particulate organic matter;

3) C-MOM: carbon of organic matter associated with minerals.

The same procedure was performed to calculate the physical fraction of nitrogen.

\subsection{Statistical Analyses}

The areas evaluated in this study are under the same topographic and edaphoclimatic conditions, differing only in relation to land use system. Therefore, the design was completely randomized and consisted of three areas (pasture, CLIS, and Cerrado). The Lilliefors test was used to evaluate the normality of errors and the Cochran test to evaluate homogeneity of variances. Afterwards, the data were submitted to the F test through analysis of variance (ANOVA). Significant data in the F test at a 5\% significance level had their means compared by the multiple-comparison Tukey test considering the same significance 5\%. These procedures were performed using the software SAEG (2007).

\section{Results and Discussion}

\subsection{Plant Residues: Quantification of Phytomass, Macronutrients, and Origin Of $\Delta^{13} c$}

Plant residues differed among samples, with higher values for the Cerrado and CLIS areas and lower values for the pasture area (Table 2). Higher contribution of plant residues was recorded in CLIS than in the pasture area and can be related to better soil fertility conditions in the former (Table 1), which favors plant growth and subsequent input and surface accumulation. The high production of plant litter in the Cerrado area is attributed to greater climatic stability under the tree canopy and the absence of anthropogenic intervention. 
Table 2: Phytomass in areas with different land use and management systems in Montividiu Goiás, Brazil.

\begin{tabular}{|l|c|}
\hline Evaluated areas & Dry Phytomass (Mg ha-1) \\
\hline Pasture & $2.56 \mathrm{~b}$ \\
\hline CLIS & $4.25 \mathrm{a}$ \\
\hline Cerrado & $5.55 \mathrm{a}$ \\
\hline CV $(\%)$ & 21.06 \\
\hline
\end{tabular}

Means followed by the same letters in the column do not differ in the Tukey test at a 5\% significance level. CV: coefficient of variation; CLIS: crop-livestock integration system.

The similarity between phytomass values in CLIS and Cerrado shows the influence that CLIS, when handled properly, has on the input of plant residues to the soil surface. These values are of fundamental importance in agricultural systems of the Cerrado, because the high rate of decomposition of plant residues in this biome has hindered the maintenance of ideal amounts of phytomass in soil surface for the correct development of NTS (Boer et al., 2007; Torres et al., 2008; Loss et al., 2016). Therefore, the use of pastures with forage grasses, such as Brachiaria, can increase phytomass production and positively contribute to carbon dynamics and nutrient cycling.

Table 3 shows the total phosphorus $(\mathrm{P})$, potassium $(\mathrm{K})$, calcium $(\mathrm{Ca})$, and magnesium $(\mathrm{Mg})$ contents in plant litter and residues in the evaluated areas. The pasture area showed the highest contents of $\mathrm{P}, \mathrm{K}$, and $\mathrm{Mg}$, while CLIS showed the lowest $\mathrm{Ca}$ and $\mathrm{Mg}$ contents. In the Cerrado area, the highest $\mathrm{Ca}$ and lowest $\mathrm{P}$ contents were observed. The lowest $\mathrm{P}$ content in the Cerrado area could be due to lower availability of total phosphorus, since the other areas had previously received phosphate fertilization. In general, plant residues from the pasture area had the highest nutrient content, which is attributed to earlier stages of decomposition, since live and dead forage (haystack) were collected in the pasture samples. Contrarily, practically all the material was on the soil in CLIS, presenting more advanced stages of decomposition of plant residues (visual observation), which were composed mainly of corn stalks.

Table 3: Total phosphorus, potassium, calcium, and magnesium contents in plant litter and residues of the areas under different land use systems and management in the Cerrado area, Goiás, Brazil.

\begin{tabular}{|c|c|c|c|c|}
\hline \multirow{2}{*}{ Evaluated areas } & $\mathbf{P}$ & $\mathbf{K}$ & $\mathbf{C a}$ & Mg \\
\hline & \multicolumn{4}{|c|}{ 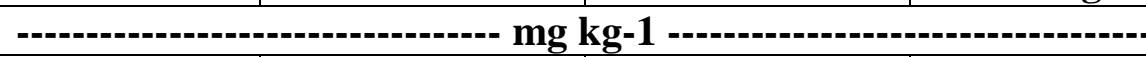 } \\
\hline Pasture & $1931 \mathrm{a}$ & $8438 \mathrm{a}$ & $3012 \mathrm{~b}$ & $6247 \mathrm{a}$ \\
\hline CLIS & $1086 \mathrm{~b}$ & $3640 \mathrm{~b}$ & $1500 \mathrm{c}$ & $2125 \mathrm{c}$ \\
\hline Cerrado & $600 \mathrm{c}$ & $4469 \mathrm{~b}$ & $4544 \mathrm{a}$ & 2998 b \\
\hline $\mathrm{CV}(\%)$ & 9.56 & 9.62 & 10.80 & 5.75 \\
\hline
\end{tabular}

Means followed by the same letters in the column do not differ in the Tukey test at a 5\% significance level. CLIS: crop-livestock integration system; CV: coefficient of variation

The high amount of nutrients found in the pasture compared to CLIS may be due to higher contents of low molecular weight components, such as sugars, amino acids, and proteins, since green and dry mass were collected in the pasture, leading to faster decomposition in the initial period and greater nutrient release. The decomposition rate decreases over time due to the accumulation of 
recalcitrant components, such as lignin, tannins, and cellulose (Giacomini et al., 2003; Lupwayi et al., 2007). In addition, there was much more dry material (corn stalks) in CLIS, which is richer in recalcitrant materials.

It is important to highlight that CLIS holds a great variation of plant species and undergoes fertilization. For different species, organic residues with different resistance to decomposition (Crusciol et al., 2005) and different levels of recalcitrance are observed (Giacomini et al., 2003). Hence, nutrient cycling in CLIS depends on the plant residues remaining on the soil surface (soybean/corn/Brachiaria/beans/cotton), which represent important nutrient reserves. The availability of these nutrients can be rapid and intense or slow and gradual, depending on the interaction between climatic factors like precipitation and temperature, which are contrasting during summer and winter in the Cerrado (Figure 2), and factors related to the biological activity of the soil and the quality and quantity of residues (Heltz et al., 2014).

Table 4 shows the carbon $(\mathrm{C})$, nitrogen $(\mathrm{N}), \delta^{13} \mathrm{C}$, and $\mathrm{C} / \mathrm{N}$ ratio values of plant litter and residues. The $\mathrm{C}$ and $\mathrm{N}$ values showed differences in all areas, with higher values for the Cerrado area (486.28 $\mathrm{g} \mathrm{kg}^{-1}$ ), followed by pasture (425.51 $\mathrm{g} \mathrm{kg}^{-1}$ ), and CLIS (364.35 $\left.\mathrm{g} \mathrm{kg}^{-1}\right)$. On the other hand, N values were also higher for the Cerrado area $\left(13.69 \mathrm{~g} \mathrm{~kg}^{-1}\right)$ followed by CLIS $\left(11.53 \mathrm{~g} \mathrm{~kg}^{-1}\right)$ and pasture $\left(5.08 \mathrm{~g} \mathrm{~kg}^{-1}\right)$ areas (Table 4).

Table 4: Carbon, nitrogen, $\delta^{13} \mathrm{C}$, and $\mathrm{C} / \mathrm{N}$ ratio of plant residues and litter in different soil management systems in the Cerrado of the state of Goiás.

\begin{tabular}{|l|c|c|c|c|}
\hline \multirow{2}{*}{ Evaluated areas } & $\mathbf{C}$ & $\mathbf{N}$ & $\boldsymbol{\delta}^{\mathbf{1 3}} \mathbf{C}$ & \multirow{2}{*}{$\mathbf{C} / \mathbf{N}$} \\
\cline { 2 - 4 } & $---------\mathrm{g} \mathrm{kg}^{-1}---------$ & $------\mathbf{\% o}^{------}$ & \\
\hline Pasture & $425.51 \mathrm{~b}$ & $5.08 \mathrm{c}$ & $-12.25 \mathrm{a}$ & $83.84 \mathrm{a}$ \\
\hline CLIS & $364.35 \mathrm{c}$ & $11.53 \mathrm{~b}$ & $-15.33 \mathrm{~b}$ & $31.64 \mathrm{c}$ \\
\hline Cerrado & $486.28 \mathrm{a}$ & $13.69 \mathrm{a}$ & $-28.67 \mathrm{c}$ & $35.62 \mathrm{~b}$ \\
\hline CV $(\%)$ & 2.06 & 5.23 & -6.25 & 3.24 \\
\hline
\end{tabular}

Means followed by the same letters in the column do not differ in the Tukey test at a 5\% significance level. C: carbon; $\mathrm{N}$ : nitrogen; $\mathrm{C} / \mathrm{N}$ : carbon/nitrogen ratio; CLIS: crop-livestock integration system; CV: coefficient of variation.

The lower $\mathrm{N}$ content in the plant residues of the pasture area provided a high $\mathrm{C} / \mathrm{N}$ ratio (83.84) different to the other areas. In CLIS and Cerrado, differences were also observed, with the C/N ratio found in the Cerrado area (35.62) being higher than the ratio recorded for the CLIS (31.64; Table 4). Thus, plant residues from the pasture area tend to have greater resistance to decomposition, resulting in slower carbon cycling in the soil-plant-atmosphere system. In contrast, a more intense land use is observed in CLIS, enabling faster C and $\mathrm{N}$ cycling in this system. Moreover, the addition of $\mathrm{N}$ in CLIS via mineral fertilization should be emphasized, as it increases both the aerial and root biomass of forage, which in turn promotes a biological plowing in soil due to abundant and aggressive root systems. Thus, residual nutrients left by preceding crops are recycled, especially $\mathrm{N}$ in CLIS (Heltz et al., 2014). According to Heltz et al. (2014), 60\% to $70 \%$ of the $\mathrm{N}$ found in plant biomass can be recycled and reabsorbed by plants in the following crop. These data differentiate CLIS from other land use systems, due to the combination and maintenance of large amounts of haystack (mainly Brachiaria in the Cerrado) on the soil, which supplies $\mathrm{N}$ for the succeeding culture (Loss et al., 2012b). 
The $\delta^{13} \mathrm{C}$ differed among all areas, according to the different origins of plant materials $\left(\mathrm{C}_{3}\right.$ or $\mathrm{C}_{4}$ photosynthetic mechanisms). In $\mathrm{C}_{3}$ plants, the isotopic composition $\left(\delta^{13} \mathrm{C}\right)$ ranges from -24 to -34 $\%$, while in $\mathrm{C}_{4}$ plants, the $\delta^{13} \mathrm{C}$ composition varies from -6 to $-19 \%$ (Smith and Epstein, 1971). Therefore, a prevalence of $\mathrm{C}_{4}$ plants, in this case grassy species (Brachiaria), can be inferred in the pasture area, which presented a value of $-12.25 \%$. The $\delta^{13} \mathrm{C}$ value of CLIS $(-15.33 \%$ ) also indicates the presence of residues of plants with $\mathrm{C}_{4}$ photosynthetic mechanisms, probably remnant plant residues from corn and Brachiaria used in the crop rotation system. The difference found between $\delta^{13} \mathrm{C}$ values recorded for CLIS and pasture is due to the presence of plants with a $\mathrm{C}_{3}$ mechanism (soybean and beans) in CLIS. In the Cerrado area, the $\delta^{13} \mathrm{C}$ value $(-28.67 \%$ ) indicates the prevalence of litter of plants with $\mathrm{C}_{3}$ photosynthetic mechanism (Table 4). Some studies have reported that $\mathrm{C}_{3}$ plants prevail in the Cerradão vegetation (Pessenda et al., 1996; Roscoe et al., 2000; Loss et al., 2012b).

\subsection{Source of $\operatorname{SOM}\left(\Delta^{13} \mathrm{C}\right)$}

The natural abundance of $\delta^{13} \mathrm{C}$ in the evaluated areas for depths up to $100 \mathrm{~cm}$ is shown in Figure 4. The $\delta^{13} \mathrm{C}$ values for the surface layer of the Cerrado area $( \pm-27 \%)$ show the prevalence of $\mathrm{C}_{3}$ plants. However, there is a gradual and constant increase of the $\delta^{13} \mathrm{C}$ values $( \pm-20 \%$ o $)$ with depth. This shows that this Cerrado area, whose specific local vegetation is Cerradão, possibly had plants with $\mathrm{C}_{4}$ mechanisms several years ago (centuries), which is a typical characteristic of the Cerrado (Balesdent and Mariotti, 1996).

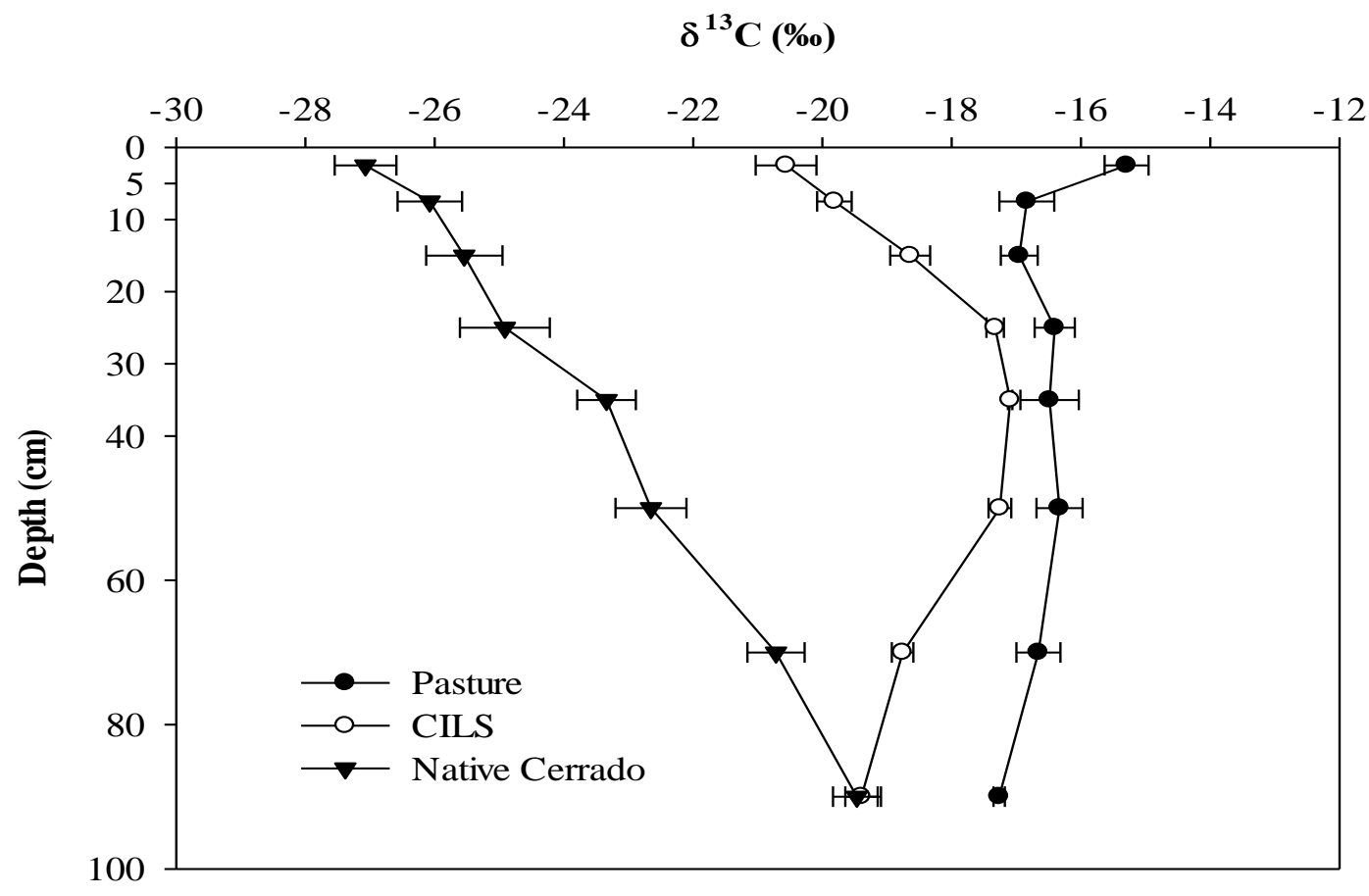

Figure 4: Natural abundance of ${ }^{13} \mathrm{C}$ in soils from pasture, CILS and native Cerrado areas up to $100 \mathrm{~cm}$ deep. Average of three replicates. Error bars indicate the standard errors of the averages. CILS: crop-livestock integration system. 
The pasture area showed constant $\delta^{13} \mathrm{C}$ values, from 5 to $100 \mathrm{~cm}$, with values near $-17 \%$. The enrichment of $\delta^{13} \mathrm{C}$ is higher only in the superficial layer of $0-5 \mathrm{~cm}$, with values near $-15 \%$ (Figure 4). This shows a considerable prevalence of $\mathrm{C}_{4}$ plants in this area. Through its residues, mainly via rhizodeposition, the pasture area has replaced most of the carbon that was withdrawn from the Cerradão vegetation from 1990 (to implant grain crops, rice, and soybean) until Brachiaria introduction in 1995 (Figure 3). After 1995, there were no more vegetation changes.

Intermediate $\delta^{13} \mathrm{C}$ values to those found in Cerrado and pasture areas are observed in CLIS (Figure 4). This pattern is also shown in Table 4 considering the $\delta^{13} \mathrm{C}$ of plant residues. The $\delta^{13} \mathrm{C}$ values indicate that this area was subject to different successions of plant species, as depicted in the history of use of the area (Figure 3). The superficial layers $(0-30 \mathrm{~cm})$ show the transition from $\mathrm{C}_{4}$ to $\mathrm{C}_{3}$ plant species (Figure 4). However, the $\delta^{13} \mathrm{C}$ values on the surface $( \pm-21 \%$ ) do not indicate the prevalence of any species. This relates to the replacement of pasture $\left(\mathrm{C}_{4}\right)$ by agricultural crops, mainly soybean $\left(\mathrm{C}_{3}\right.$ plant). Beans and cotton ( $\mathrm{C}_{3}$ plants) have also been introduced in the crop rotation system. Some similarities in $\delta^{13} \mathrm{C}$ enrichment between CLIS and pasture areas is observed in the 20-40 cm layers (Figure 4). This relates to the period in which the area was used exclusively as pasture (Figure 3). In the 60-100 cm layers, values like those observed in the Cerrado area (Figure 4) were obtained, indicating that this area, in accordance with land use history (Figure 3), had native Cerrado vegetation before the exclusive cultivation of pasture in CLIS. In general, a convergence in the enrichment of $\delta^{13} \mathrm{C}$ is observed in the $80-100 \mathrm{~cm}$ layer in all the evaluated areas. This shows that before the areas were anthropized, the vegetation of the studied sites had similar characteristics, especially the Cerrado and CLIS areas, which presented the same $\delta^{13} \mathrm{C}$ values in the $80-100 \mathrm{~cm}$ layer.

The $\delta^{13} \mathrm{C}$ values of CLIS and pasture areas up to the $80 \mathrm{~cm}$ depth were compared with those obtained for the Cerrado area, showing an isotopic enrichment (less negative carbon values) in CLIS and pasture areas (Figure 4). These results indicate the substitution of carbon from the Cerrado vegetation (typically $C_{3}$ ) by a new carbon, from vegetation with $\mathrm{C}_{4}$ photosynthetic mechanisms, such as Brachiaria and corn. Similar results were reported by Loss et al., (2014), who evaluated $\delta^{13} \mathrm{C}$ in soil up to $100 \mathrm{~cm}$ depth in CLIS (corn + Brachiaria/beans/cotton/soybean) and Cerrado in the state of Goiás. The authors found $\delta^{13} \mathrm{C}$ values ranging from $-26.26 \%$ (0.0-10.0 $\mathrm{cm})$ to $-23.02 \%$ o $(80.0-100.0 \mathrm{~cm})$ in the Cerrado and -17.53 to $-15.50 \%$ in CLIS up to $50 \mathrm{~cm}$. Then, an isotopic decrease was observed, with values ranging from -16.07 to $-17.43 \%$ in CLIS up to $100 \mathrm{~cm}$.

\subsection{Total Organic Carbon (TOC) and Total Nitrogen (TN) of the Soil}

The TOC and TN contents presented similar patterns at soil depths of $0-5$ and $5-10 \mathrm{~cm}$ in the evaluated areas. The highest values were observed in the Cerrado, and the lowest values in CLIS and pasture areas, without differences between the latter (Table 5). The highest TOC and TN contents recorded in the Cerrado area are a consequence of higher $\mathrm{C}$ and $\mathrm{N}$ contents of the plant litter of Cerrado vegetation (Table 3), since plant litter is the most relevant compartment for $\mathrm{C}$ and $\mathrm{N}$ input when comparing with the other land use systems. However, the absence of differences between TOC and TN contents when comparing CLIS and pasture areas shows the stability of TOC and TN in CLIS, since areas with well managed pastures are considered systems with great stability regarding carbon and nitrogen dynamics (Corraza et al., 1999; Salton et al., 2011). It 
should be noted that the pasture area of this study was formed 15 years ago and has been managed in a grazing system suitable for the productive capacity of the area, always avoiding excessive grazing.

Table 5: Total organic carbon, nitrogen, and carbon/nitrogen ratio in different soil management systems in the Cerrado of the state of Goiás, Brazil.

\begin{tabular}{|c|c|c|c|}
\hline \multirow{3}{*}{ Evaluated areas } & TOC & $\mathbf{T N}$ & \multirow{2}{*}{$\mathrm{C} / \mathrm{N}$} \\
\hline & \multicolumn{2}{|c|}{ 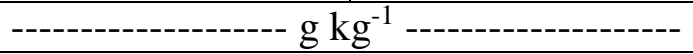 } & \\
\hline & \multicolumn{3}{|c|}{$0-5 \mathrm{~cm}$} \\
\hline Pasture & $36.43 \mathrm{~b}$ & $1.94 \mathrm{~b}$ & $18.84 \mathrm{a}$ \\
\hline CLIS & $29.61 \mathrm{~b}$ & $1.69 \mathrm{~b}$ & $17.55 \mathrm{~b}$ \\
\hline Cerrado & $65.40 \mathrm{a}$ & $3.45 \mathrm{a}$ & $18.99 \mathrm{a}$ \\
\hline \multirow[t]{2}{*}{$\mathrm{CV}(\%)$} & 13.61 & 14.70 & 2.26 \\
\hline & \multicolumn{3}{|c|}{$5-10 \mathrm{~cm}$} \\
\hline Pasture & $24.20 \mathrm{~b}$ & $1.24 \mathrm{~b}$ & $19.47 \mathrm{a}$ \\
\hline CLIS & $24.27 \mathrm{~b}$ & $1.32 \mathrm{~b}$ & $18.33 \mathrm{~b}$ \\
\hline Cerrado & $33.61 \mathrm{a}$ & $1.93 \mathrm{a}$ & $17.39 \mathrm{~b}$ \\
\hline \multirow[t]{2}{*}{$\mathrm{CV}(\%)$} & 8.33 & 8.03 & 3.60 \\
\hline & \multicolumn{3}{|c|}{$10-20 \mathrm{~cm}$} \\
\hline Pasture & $18.34 \mathrm{c}$ & $0.94 \mathrm{~b}$ & $19.48 \mathrm{~b}$ \\
\hline CLIS & $23.49 \mathrm{~b}$ & $1.11 \mathrm{~b}$ & $21.13 \mathrm{a}$ \\
\hline Cerrado & $30.15 \mathrm{a}$ & $1.69 \mathrm{a}$ & $17.75 \mathrm{c}$ \\
\hline \multirow[t]{2}{*}{$\mathrm{CV}(\%)$} & 12.21 & 9.68 & 3.96 \\
\hline & \multicolumn{3}{|c|}{$20-40 \mathrm{~cm}$} \\
\hline Pasture & $16.45 \mathrm{a}$ & $0.83 \mathrm{~b}$ & $19.83 \mathrm{ab}$ \\
\hline CLIS & $17.46 \mathrm{a}$ & $0.88 \mathrm{ab}$ & $19.94 \mathrm{a}$ \\
\hline Cerrado & $16.48 \mathrm{a}$ & $1.01 \mathrm{a}$ & $16.62 \mathrm{~b}$ \\
\hline $\mathrm{CV}(\%)$ & 6.29 & 11.37 & 10.26 \\
\hline
\end{tabular}

Means followed by the same letters in the column do not differ in Tukey test at a 5\% significance level; TOC: total organic carbon; TN: total nitrogen; $\mathrm{C} / \mathrm{N}$ : carbon/nitrogen ratio; $\mathrm{CV}$ : coefficient of variation; CLIS: crop-livestock integration system

At a depth of 10-20 cm, CLIS presented higher TOC contents than pasture (Table 5). This shows the positive effects of CLIS, since carbon input occurs through plant residues of the crops, as well as via rhizodeposition of Brachiaria and waste of animals during grazing. Forage grasses have the potential to store most of the carbon below the surface (Salton et al., 2011), since pasture roots have a large capacity to accumulate carbon in the soil (Lal, 2002). This pattern is also shown in the 20-40 cm layer, where no differences were observed in TOC levels among the evaluated areas (Table 5). The CLIS developed in the NTS favors increased input of plant residues to the soil using crops and pastures, which provides increased TOC contents and stocks, especially in production systems that do not use pastures in the rotation of cultures (Loss et al., 2012a; Heltz et al., 2014). The TN values were higher for the Cerrado area in all soil layers evaluated, with the exception of the last layer $(20-40 \mathrm{~cm})$, where CLIS did not differ from the Cerrado area. No differences were found between TN contents of CLIS and pasture areas. As recorded for TOC, the NT contents in the 20-40 $\mathrm{cm}$ layer in CLIS did not differ from those found in pasture and Cerrado areas (Table 
5). This is due to the similarity between TOC and TN dynamics in the soil, where only the mechanisms of additions and losses vary (Bayer et al., 2000; Lovato et al., 2004).

The $\mathrm{C} / \mathrm{N}$ ratio was lower at the depth of $0-5$ and 5-10 $\mathrm{cm}$ in CLIS but did not significantly differ from the 5-10 cm layer of the Cerrado area. The lowest $\mathrm{C} / \mathrm{N}$ ratio in the $10-20$ and $20-40 \mathrm{~cm}$ layers was observed for the Cerrado area, although it did not differ from the 20-40 cm layer of the pasture area. The $\mathrm{C} / \mathrm{N}$ ratio of the Cerrado area decreased with increasing depth, which can be explained by the higher stability of humic compounds in deeper layers, in addition to higher $\mathrm{N}$ contents present in the plant litter (Table 4 ). The $\mathrm{C} / \mathrm{N}$ ratio in the $0-5$ and 5-10 cm layers was higher in the pasture area than in CLIS (Table 5). This is a consequence of the origin of plant residues in the pasture, which have lower $\mathrm{N}$ contents and high $\mathrm{C} / \mathrm{N}$ ratio (Table 4 ).

The variation found in CLIS for $\mathrm{C} / \mathrm{N}$ ratio values is possibly related to the different origins of organic residues in the area. In other words, different cultivated crops (soybean, beans, corn, cotton, and Brachiaria) could be under the influence of Brachiaria through a root system at greater depths, resulting in the higher $\mathrm{C} / \mathrm{N}$ ratios, as well as higher TOC contents observed in the 10-20 $\mathrm{cm}$ layer. This is supported by the similarity between C/N ratios of CLIS and pasture areas in the $20-40 \mathrm{~cm}$ layer. It is also believed that higher $\mathrm{C} / \mathrm{N}$ ratios at greater depths in CLIS are consequence of faster carbon dynamics, which in turn reduce humification rates of SOM. Similar C/N ratio values to those of this study were reported by Loss et al., (2012a), who recorded values of 21 and 18 at the depths of 20-30 and 30-40 cm, respectively, in CLIS; and 12.5 at both depths, in the Cerrado of Goiás, Brazil.

\subsection{Light Organic Matter: Mass Quantification and $\mathrm{C}$ and $\mathrm{N}$ Content}

The Cerrado area presented the highest mass values of light organic matter (M-LOM) at the two evaluated depths (Table 6). These values are consequence of the higher contribution of plant litter in this area (Table 2), which is associated with an environment with high-volume of roots from natural vegetation. The plants of the natural vegetation form a large network of fine roots, especially in the superficial layer, to absorb nutrients provided by the plant litter (Menezes et al., 2010).

Table 6: Mass of light organic matter (M-LOM) in water under different soil management systems in the Cerrado of the state of Goiás, Brazil.

\begin{tabular}{|l|c|c|}
\hline \multirow{2}{*}{ Evaluated areas } & \multicolumn{2}{|c|}{ M-LOM } \\
\cline { 2 - 3 } & $\mathbf{0 - 5} \mathbf{~ c m}$ & $\mathbf{5}-\mathbf{1 0} \mathbf{~ c m}$ \\
\cline { 2 - 3 } & $----------------------\mathrm{g} \mathrm{kg}^{-1}----------------------$ \\
\hline Pasture & $5.16 \mathrm{~b}$ & $4.51 \mathrm{~b}$ \\
\hline CLIS & $4.77 \mathrm{~b}$ & $1.59 \mathrm{c}$ \\
\hline Cerrado & $22.38 \mathrm{a}$ & $8.51 \mathrm{a}$ \\
\hline CV $(\%)$ & 15.90 & 25.76 \\
\hline
\end{tabular}

Means followed by the same letters in the column do not differ by Tukey test at a 5\% significance level; CV: coefficient of variation; CLIS: crop-livestock integration system.

The obtained M-LOM values for CLIS and pasture areas did not differ at the depth of 0-5 cm. However, a lower M-LOM value was observed for CLIS at the depth of 5-10 cm. This can be 
attributed to the lower $\mathrm{C} / \mathrm{N}$ ratios of LOM (Table 7) and plant residues in this area than in the pasture and Cerrado areas (Table 2). The similarity of M-LOM values between CLIS and pasture in the 0-5 cm layer may be related to the presence of grasses (such as corn and Brachiaria) in the crop rotation system of CLIS. These plants have higher $\mathrm{C} / \mathrm{N}$ ratios, and thus longer residence time in the soil. This was also observed by Loss et al., (2012b) when studying M-LOM in CLIS, NTS, and native Cerrado of the state of Goiás with Dystrophic Oxisols. The authors found higher MLOM values in CLIS and Cerrado than in NTS, which did not use Brachiaria in crop rotation.

Comparing CLIS and pasture areas in the 5-10 cm layer, higher values of M-LOM are observed in the pasture area because it presents a root system with large number of fine roots, associated with forage permanence in the pasture and adequate grazing in the area.

The carbon contents of LOM (C-LOM) did not differ among areas, in the two evaluated layers (Table 7). However, the nitrogen contents of LOM (N-LOM) differed among all the evaluated areas, showing the same pattern in the two evaluated layers. The highest N-LOM values were observed in CLIS and the lowest values in the pasture area.

Table 7: Carbon $(\mathrm{C})$, nitrogen $(\mathrm{N})$, and $\mathrm{C} / \mathrm{N}$ ratio values for light organic matter (LOM) of the soil in areas of different management systems.

\begin{tabular}{|l|c|c|c|c|c|}
\hline \multirow{2}{*}{ Attributes } & \multirow{2}{*}{ Depth (cm) } & \multicolumn{3}{|c|}{ Evaluated areas } & \multirow{2}{*}{ CV (\%) } \\
\cline { 2 - 6 } & & Pasture & CLIS & Cerrado & \\
\hline \multirow{2}{*}{ C-LOM $\left(\mathrm{g} \mathrm{kg}^{-1}\right)$} & $0-5$ & $276.72 \mathrm{a}$ & $291.74 \mathrm{a}$ & $314.58 \mathrm{a}$ & 9.29 \\
\cline { 2 - 6 } & $5-10$ & $283.59 \mathrm{a}$ & $288.97 \mathrm{a}$ & $321.29 \mathrm{a}$ & 10.48 \\
\hline \multirow{2}{*}{$\mathrm{N}-L O M\left(\mathrm{~g} \mathrm{~kg}^{-1}\right)$} & $0-5$ & $6.87 \mathrm{c}$ & $16.33 \mathrm{a}$ & $9.51 \mathrm{~b}$ & 11.70 \\
\cline { 2 - 6 } & $5-10$ & $6.81 \mathrm{c}$ & $16.08 \mathrm{a}$ & $12.77 \mathrm{~b}$ & 10.13 \\
\hline \multirow{2}{*}{$\mathrm{C} / \mathrm{N}-L O M$} & $0-5$ & $40.34 \mathrm{a}$ & $17.83 \mathrm{c}$ & $24.86 \mathrm{~b}$ & 8.46 \\
\cline { 2 - 6 } & $5-10$ & $41.62 \mathrm{a}$ & $17.99 \mathrm{c}$ & $25.28 \mathrm{~b}$ & 4.17 \\
\hline
\end{tabular}

Means followed by the same letter in the row do not differ in the Tukey test at a 5\% significance level. CV: coefficient of variation; CLIS: crop-livestock integration system.

The higher N-LOM values recorded in CLIS are possibly related to the nitrogen fertilization carried out in agricultural crops. This practice enables part of the applied $\mathrm{N}$ to remain in the culture residues, including the LOM. Furthermore, soybean cultivation increases soil $\mathrm{N}$ through biological fixation. In addition to the increased $\mathrm{N}$ in CLIS, the use of grasses such as Brachiaria can extract nutrients from the soil at greater depths, which then are released at the soil surface during the decomposition of the grasses, may also produce higher N-LOM values in CLIS.

In the Cerrado area, it is possible that the presence of native plants (leguminous crops), with biological fixation potential, are assisting in the maintenance of $\mathrm{N}$ and its dynamic in this native area. Variations in $\mathrm{C} / \mathrm{N}$ ratios were recorded among all areas due to N-LOM differences (Table 7). The highest $\mathrm{C} / \mathrm{N}$ ratios were observed in the pasture area, followed by the Cerrado and CLIS areas. This difference causes an important impact on the carbon dynamics among areas, being more intense in areas with lower C/N ratios (CLIS). Similar results were reported by Loss et al (2012b) in CLIS and Cerrado areas in Goiás. The authors found mean C-LOM values of 315 and $340 \mathrm{~g} \mathrm{~kg}^{-}$ ${ }^{1}$, mean N-LOM values of 16.0 and $15.0 \mathrm{~g} \mathrm{~kg}^{-1}$, and mean C/N values of 18.0 and 23.0 for the CLIS and the Cerrado areas, respectively, in the $0-10 \mathrm{~cm}$ layer. 


\subsection{Physical Particle Size Fractionation of SOM: Quantification and Contribution of C and $\mathbf{N}$ Contents}

The carbon (Table 8) and nitrogen contribution values (Table 9) from the physical particle size fractions (in relation to the TOC) had a similar pattern in the $0-5 \mathrm{~cm}$ layer. However, the Cerrado area differed from the others, presenting the highest values. The higher values in the Cerrado are attributed to the greater contribution of plant litter (Table 1) and lack of anthropic disturbances in this area. Salton et al. (2011) studied Cerrado areas in the state of Mato Grosso do Sul and concluded that higher amounts of organic matter of higher lability (C-LOM and C-POM) are associated with higher inputs of plant material.

Table 8: Carbon contribution from the physical particle size fractions regarding the total organic carbon (TOC) under different soil management systems in the Cerrado of the state of Goiás,

Brazil.

\begin{tabular}{|c|c|c|c|c|}
\hline \multirow{3}{*}{ Evaluated areas } & C-LOM & C-POM & C-MOM & TOC \\
\hline & \multicolumn{4}{|c|}{ 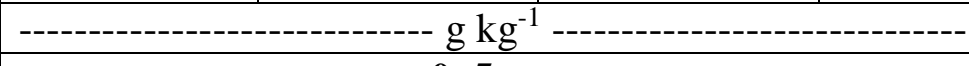 } \\
\hline & \multicolumn{4}{|c|}{$0-5 \mathrm{~cm}$} \\
\hline Pasture & $1.59(4.3) \mathrm{b}$ & $6.70(18,4) b$ & $28.18(77.3) b$ & $36.43 \mathrm{~b}$ \\
\hline CLIS & $1.37(4.6) \mathrm{b}$ & $6.34(21,5) b$ & $21.88(73.9) b$ & $29.61 \mathrm{~b}$ \\
\hline Cerrado & $7.01(10.7) \mathrm{a}$ & $16.37(25.0) \mathrm{a}$ & $42.02(64.3) \mathrm{a}$ & $65.40 \mathrm{a}$ \\
\hline \multirow[t]{2}{*}{$\mathrm{CV}(\%)$} & 14.57 & 25.96 & 19.54 & 13.61 \\
\hline & \multicolumn{4}{|c|}{$5-10 \mathrm{~cm}$} \\
\hline Pasture & $1.28(5.3) b$ & $7.21(29.8) b$ & $15.70(64.9) b$ & $24.20 \mathrm{~b}$ \\
\hline CLIS & $0.45(1.9) \mathrm{c}$ & $2.91(12.0) \mathrm{c}$ & $20.91(86.1) \mathrm{a}$ & $24.27 \mathrm{~b}$ \\
\hline Cerrado & $2.72(8.1) \mathrm{a}$ & $9.79(29.1) \mathrm{a}$ & $21.09(62.8) \mathrm{a}$ & $33.61 \mathrm{a}$ \\
\hline $\mathrm{CV}(\%)$ & 25.42 & 23.03 & 11.79 & 8.33 \\
\hline
\end{tabular}

Means followed by the same letter in the column of each depth do not differ in the Tukey test at a 5\% significance level. The values between parentheses are the percentage of carbon of the fraction regarding TOC. CLIS: livestock farming a system; C-LOM: light organic carbon; C-POM: particulate organic carbon; C-MOM: organic carbon associated with minerals; CV: coefficient of variation.

No differences in carbon and nitrogen values between pasture and CLIS areas in the $0-5 \mathrm{~cm}$ layer were observed in all evaluated fractions. For CLIS, this can be considered a great benefit regarding the increase of labile fractions of SOM, since the pasture area keeps the soil permanently covered, in addition to the appropriate grazing. However, CLIS undergoes stages in the productive process that favors SOM decomposition, such as the desiccation of cover crops and sowing. The inadequate increase of organic matter (C-LOM and C-POM) leads to reduced TOC, which reduces quality and increases degradation of the soil (Causarano et al., 2008).

The percent distribution of the different carbon forms showed a similar pattern in the two anthropized areas. These values are approximately 4.5\%,20\%, and $75 \%$ for the fractions C-LOM, C-POM, and C-MOM, respectively (Table 8). The carbon values of the fractions were also higher for the Cerrado area in the 5-10 cm layer but did not differ from CLIS for the C-MOM. These higher C-MOM values in CLIS and Cerrado areas can be due to greater phytomass accumulation in these areas (Table 2), which leads to more intense cycling due to lower $\mathrm{C} / \mathrm{N}$ ratio values of plant residues (Table 3) and LOM (Table 7). More humidified organic compounds, such as C-MOM, can be formed with higher carbon cycling and higher $\mathrm{N}$ contents (Tables 3 and 7). The carbon 
contents of the physical fractions of the pasture and CLIS areas in the 5-10 cm layer showed lower values for C-LOM and C-POM in CLIS (Table 8). These differences may be due to the greater susceptibility of the C-POM and C-LOM fractions to variations imposed by the soil management when compared to TOC and C-MOM. In addition, CLIS holds more nitrogen-rich plant residues (Table 4), as well as higher $\mathrm{N}$ levels in LOM (Table 7), which leads to lower C/N values in CLIS than in pasture. This foster higher $\mathrm{C}$ and $\mathrm{N}$ cycling in LOM and POM in CLIS than in pasture. Some studies (Rangel and Silva, 2007; Pereira et al., 2010; Frazão et al., 2010) have suggested greater sensitivity of lighter fractions of SOM to soil management.

The nitrogen fractions presented greater variation than the carbon fractions in the percentage distribution for the 0-5 cm layer. In CLIS, nitrogen participation in forms associated with the most labile fractions (N-LOM and N-POM) was higher than the fractions of the pasture area (Table 9). This is probably due to the use of nitrogen fertilization and cultivation of leguminous plants (soybeans and beans) in the crop rotation system, which provide more nitrogen-enriched residues.

Table 9: Nitrogen contribution of the physical particle size fractions regarding total nitrogen (TN) under different soil management systems in the Cerrado of the state of Goiás, Brazil.

\begin{tabular}{|l|c|c|c|c|}
\hline \multirow{2}{*}{ Evaluated areas } & N-LOM & N-POM & N-MOM & TN \\
\cline { 2 - 5 } & $-------------------\mathrm{g} \mathrm{kg}^{-1}$ & \multicolumn{5}{|c|}{$\mathbf{0}-\mathbf{5} \mathbf{~ c m}$} \\
\cline { 2 - 5 } & $0.04(2.0) \mathrm{b}$ & $0.38(19.6) \mathrm{b}$ & $1.52(78.4) \mathrm{b}$ & $1.94 \mathrm{~b}$ \\
\hline Pasture & $0.08(4.6) \mathrm{b}$ & $0.40(23.7) \mathrm{b}$ & $1.21(71.7) \mathrm{b}$ & $1.69 \mathrm{~b}$ \\
\hline CLIS & $0.28(8.2) \mathrm{a}$ & $1.02(29.5) \mathrm{a}$ & $2.15(62.3) \mathrm{a}$ & $3.45 \mathrm{a}$ \\
\hline Cerrado & 20.62 & 15.51 & 20.17 & 14.70 \\
\hline CV $(\%)$ & $0.03(2.5) \mathrm{b}$ & $0.34(27.4) \mathrm{b}$ & $0.87(70.1) \mathrm{c}$ & $1.24 \mathrm{~b}$ \\
\hline & $0.03(1.9) \mathrm{b}$ & $0.17(12.7) \mathrm{c}$ & $1.13(85.4) \mathrm{b}$ & $1.32 \mathrm{~b}$ \\
\hline Pasture & $0.12(5.6) \mathrm{a}$ & $0.51(26.5) \mathrm{a}$ & $1.31(67.9) \mathrm{a}$ & $1.93 \mathrm{a}$ \\
\hline CLIS & 28.74 & 21.14 & 9.00 & 8.03 \\
\hline CV $(\%)$ & &
\end{tabular}

Means followed by the same letter in the column of each depth do not differ in the Tukey test at a 5\% significance level. The values between parentheses represent the percentage of nitrogen of the fraction in relation to TN. CLIS: crop-livestock integration system; N-LOM: nitrogen of light organic matter; N-POM: nitrogen of particulate organic matter; N-MOM: nitrogen of organic matter associated with minerals; CV: coefficient of variation.

No differences were observed between N-LOM, N-POM, and N-MOM for the $0-5 \mathrm{~cm}$ soil surface layer of CLIS and pasture areas, a pattern similar to the one recorded for carbon. In CLIS, this is related to nitrogen fertilization and crop rotation, while in pasture, it is related to the continuous use of Brachiaria and proper grazing. When compared with the pasture area, CLIS presented similar N-LOM, lower N-POM, and greater N-MOM values in the 5-10 cm layer (Table 9). The CLIS showed the lowest C-MOM variation between the 0-5 and 5-10 cm layers. Also, CLIS showed higher C-MOM levels than the pasture area. Carbon and nitrogen tended to prevail in MOM form in CLIS, especially in the $5-10 \mathrm{~cm}$ layer. This is due to the higher resistance of this fraction to management practices despite of the lower resistance of LOM and POM fractions.

The $\mathrm{C} / \mathrm{N}$ ratio of the LOM fraction (CN-LOM) has been previously discussed (Table 7). The $\mathrm{C} / \mathrm{N}$ ratio of POM (CN-POM) and of MOM (CN-MOM) did not differ between areas in the $0-5 \mathrm{~cm}$ layer (Table 10). The 5-10 cm layer of the pasture area presented the highest CN-POM values. 
Also, it higher $\mathrm{CN}-\mathrm{MOM}$ values than the Cerrado. The higher $\mathrm{C} / \mathrm{N}$ ratios in the pasture area are explained by the higher $\mathrm{C} / \mathrm{N}$ ratio of plant residues (Table 4).

Table 10: Carbon/nitrogen ratio $(\mathrm{C} / \mathrm{N})$ of the soil physical particle size fractions under different management systems in the Cerrado of the state of Goiás, Brazil.

\begin{tabular}{|l|c|c|c|c|}
\hline \multirow{2}{*}{ Evaluated areas } & CN-LOM & CN-POM & CN-MOM & CN-S \\
\cline { 2 - 5 } & ---------- \\
\cline { 2 - 5 } & $40.34 \mathrm{a}$ & $17.69 \mathrm{a}$ & $18.64 \mathrm{a}$ & $18.84 \mathrm{a}$ \\
\hline Pasture & $17.83 \mathrm{c}$ & $15.97 \mathrm{a}$ & $18.06 \mathrm{a}$ & $17.55 \mathrm{~b}$ \\
\hline CLIS & $24.86 \mathrm{~b}$ & $15.94 \mathrm{a}$ & $19.63 \mathrm{a}$ & $18.99 \mathrm{a}$ \\
\hline Cerrado & 8.46 & 11.32 & 5.62 & 2.26 \\
\hline CV (\%) & $41.62 \mathrm{a}$ & $20.97 \mathrm{a}$ & $18.08 \mathrm{a}$ & $19.47 \mathrm{a}$ \\
\hline & $17.99 \mathrm{c}$ & $17.48 \mathrm{~b}$ & $18.46 \mathrm{a}$ & $18.33 \mathrm{~b}$ \\
\hline Pasture & $25.28 \mathrm{~b}$ & $19.05 \mathrm{ab}$ & $16.06 \mathrm{~b}$ & $17.39 \mathrm{~b}$ \\
\hline CLIS & 4.17 & 6.35 & 6.51 & 3.60 \\
\hline CV
\end{tabular}

Means followed by the same letter in the column of each depth do not differ in the Tukey test at a 5\% significance level. CLIS: crop-livestock integration system; CN-LOM: carbon/nitrogen ratio of light organic matter; CN-POM: carbon/nitrogen ratio of particulate organic matter; CN-MOM: carbon/nitrogen ratio of organic matter associated with minerals; $\mathrm{CN}-\mathrm{S}$ : carbon/nitrogen ratio of soil; $\mathrm{CV}$ : coefficient of variation.

It is important to note that CN-POM values were proportionally smaller in the $0-5 \mathrm{~cm}$ layer than in the 5-10 cm layer (Table 10). This can be explained by higher intensity of microbial activity in the surface layer (Beutler et al., 2016), with POM being an important nutrient source for soil biota, especially of carbon and nitrogen. In the superficial layer, the gas exchange of the soil with the atmosphere is more intense. Greater presence of free-living nitrogen-fixing bacteria, which supply their carbon requirements from sources such as LOM and POM, may also occur.

The CN-MOM was lower in the Cerrado area (5-10 cm layer) than the pasture and CLIS areas. Areas of greater chemical and physical stability in SOM dynamics are expected to have more stable carbon in the more recalcitrant fractions of deeper layers (Favoretto et al., 2008).

\section{6. $\Delta^{13} \mathrm{C}$ AND $\Delta^{15} \mathrm{~N}$ of Physical Particle Size Fractions of SOM}

The $\delta^{13} \mathrm{C}$ values of LOM, POM, and soil in the two evaluated layers were all higher in the pasture area, followed by CLIS and Cerrado areas (Table 11). As previously discussed (Table 4), the prevalence of plants with $\mathrm{C}_{4}$ photosynthetic mechanisms in the pasture area and $\mathrm{C}_{3}$ in the Cerrado area is clearly verified. On the other hand, CLIS showed intermediate values, indicating mixed occurrences of $\mathrm{C}_{3}$ and $\mathrm{C}_{4}$ plants. Different patterns within each evaluated area regarding the variation of $\delta^{13} \mathrm{C}$ values were observed between LOM, POM, and soil, with more negative $\delta^{13} \mathrm{C}$ values in LOM than in POM and soil in the pasture area. In soil, the $\delta^{13} \mathrm{C}$ values are higher (more negative), but do not differ from POM values in the two evaluated layers. Differences among $\delta^{13} \mathrm{C}$ values of LOM, POM, and soil were observed in the two layers evaluated in the CLIS area, with the soil exhibiting the higher values, followed by POM and LOM. The $\delta^{13} \mathrm{C}$ of soil and LOM differed in the Cerrado area, being significantly higher for soil, whereas POM showed intermediate values, statistically not differing from soil and $\mathrm{LOM} \delta^{13} \mathrm{C}$ (Table 11). 
Table 11: Natural abundance of ${ }^{13} \mathrm{C}$ in light organic matter (LOM), particulate organic matter (POM), and soil under different management areas in the Cerrado of the state of Goiás, Brazil.

\begin{tabular}{|c|c|c|c|c|}
\hline \multirow{3}{*}{ Evaluated Areas } & LOM & POM & Soil & \multirow{2}{*}{ CV $(\%)$} \\
\hline & \multicolumn{3}{|c|}{-- } & \\
\hline & \multicolumn{3}{|c|}{ 0-5 cm } & \\
\hline Pasture & $-13.79 \mathrm{aA}$ & $-14.46 \mathrm{aAB}$ & $-15.29 \mathrm{aB}$ & -3.89 \\
\hline CLIS & $-24.17 b C$ & $-21.64 b B$ & $-20.56 \mathrm{bA}$ & -2.41 \\
\hline Cerrado & $-28.53 \mathrm{cB}$ & $-28.18 \mathrm{cAB}$ & $-27.07 \mathrm{cA}$ & -2.18 \\
\hline \multirow[t]{2}{*}{$\mathrm{CV}(\%)$} & -1.65 & -2.82 & -3.58 & \\
\hline & \multicolumn{3}{|c|}{$5-10 \mathrm{~cm}$} & \\
\hline Pasture & $-13.80 \mathrm{aA}$ & $-15.80 \mathrm{aB}$ & $-16.84 \mathrm{aB}$ & -5.45 \\
\hline CLIS & $-24.29 \mathrm{bC}$ & $-20.96 \mathrm{bB}$ & $-19.81 \mathrm{bA}$ & -1.70 \\
\hline Cerrado & $-27.62 \mathrm{cB}$ & $-27.45 \mathrm{cAB}$ & $-26.08 \mathrm{cA}$ & -2.61 \\
\hline $\mathrm{CV}(\%)$ & -1.79 & -4.04 & -3.38 & \\
\hline
\end{tabular}

Means followed by the same lowercase letter in the column and uppercase letter in the row do not differ in the Tukey test at a 5\% significance level. CLIS: crop-livestock integration system; CV: coefficient of variation.

The $\delta^{13} \mathrm{C}$ values of the less stable fraction (LOM) tends to be similar to the values observed in plant and litter residues of the pasture and Cerrado areas (Table 4). In CLIS, this pattern was not observed, since the plant residues showed $\delta^{13} \mathrm{C}$ of values of $15.33 \%$ and LOM values of approximately $-24 \%$ (Table 11 ). This is explained by the dynamism of the crop rotation system between $\mathrm{C}_{3}$ (soybean, cotton, and bean) and $\mathrm{C}_{4}$ (corn and Brachiaria) plants. Possibly, LOM fractions of this area had higher proportions of fine roots (live and dead) of the cotton crop, which was being cultivated at the time of sampling.

The $\delta^{13} \mathrm{C}$ values of POM fractions showed a pattern similar to those observed in soil. Thus, comparing the LOM and POM fractions it is possible to infer that the POM fraction better represents the origin of medium-term organic residues, while LOM was efficient to identify the origin of short-term. In other words, LOM is associated with the input of recent (new) carbon, especially from the plant residues of plants present at the time of soil collection. On the other hand, POM, which has already undergone the decomposition of plant residues, represents the carbon that has undergone processes of physical and chemical transformation. In general, these studies may contribute to the understanding of the stages and variations during the process of decomposition of litter and plant residues, which probably undergo different physical and chemical forms within SOM dynamics, among which are LOM and POM.

The $\delta^{15} \mathrm{~N}$ of LOM did not differ among areas in the two evaluated layers $(\mathrm{p}>0.05)$. The $\delta^{15} \mathrm{~N}$ of POM was higher for the pasture and CLIS areas in the $0-5 \mathrm{~cm}$ layer. No differences between areas were observed for the 5-10 cm layer $(\mathrm{p}>0.05)$. The $\delta^{15} \mathrm{~N}$ values of the soil were higher for the pasture and CLIS areas in the two evaluated layers (Table 12). The higher $\delta^{15} \mathrm{~N}$ values for soil and POM in the pasture and CLIS areas may be due to the higher mineralization of SOM and $\mathrm{N}$ assimilation by plants, as this leads to greater decomposition of the lighter $\mathrm{N}$ isotope $\left({ }^{14} \mathrm{~N}\right)$, leaving the remaining SOM with higher $\delta^{15} \mathrm{~N}$ values (Hogberg, 1997). Similar results were found by Costa Junior et al., (2011) evaluating the $\delta^{15} \mathrm{~N}$ of the soil of pasture areas, NTS, and Cerrado in GO. Lower values were found in the Cerrado (4.30\%) than in the pasture (6.30\%) and NTS (5.50 \%o). 
The comparison of the $\delta^{15} \mathrm{~N}$ values of LOM, POM, and soil in each area showed that LOM had the lowest $\delta^{15} \mathrm{~N}$ values for the pasture and CLIS areas in both evaluated layers. On the other hand, no differences between the LOM and POM fractions and the soil were detected at any depth in the Cerrado area $(\mathrm{p}>0.05)$. The POM presented $\delta^{15} \mathrm{~N}$ values similar to those observed for the soil, except for CLIS in the 0-5 cm layer, where values for POM were lower than in the soil, but higher than in LOM (Table 12).

Table 12: Natural abundance of $15 \mathrm{~N}$ in light organic matter (LOM), particulate organic matter (PMO), and soil under different management areas in the Cerrado of the state of Goiás, Brazil.

\begin{tabular}{|c|c|c|c|c|}
\hline \multirow{3}{*}{ Evaluated Areas } & LOM & POM & Soil & \multirow{2}{*}{ CV $(\%)$} \\
\hline & \multicolumn{3}{|c|}{---------------- $\delta^{15}$ N (\%o) ----------------- } & \\
\hline & \multicolumn{3}{|c|}{ 0-5 cm } & \\
\hline Pasture & $2.14{ }^{\mathrm{ns}} B$ & $4.73 \mathrm{aA}$ & $5.05 \mathrm{aA}$ & 20.90 \\
\hline CLIS & $2.37{ }^{\mathrm{ns}} \mathrm{C}$ & $4.06 \mathrm{aB}$ & $5.40 \mathrm{aA}$ & 10.25 \\
\hline Cerrado & $2.44^{\mathrm{ns}}$ & $1.78 b^{\mathrm{ns}}$ & $3.33 b^{n s}$ & 25.80 \\
\hline \multirow[t]{2}{*}{$\mathrm{CV}(\%)$} & 16.99 & 15.92 & 13.07 & \\
\hline & \multicolumn{3}{|c|}{$5-10 \mathrm{~cm}$} & \\
\hline Pasture & $3.50^{\mathrm{ns}} B$ & $5.25^{\mathrm{ns}} \mathrm{A}$ & $6.59 \mathrm{aA}$ & 14.35 \\
\hline CLIS & $3.99^{\mathrm{ns}} B$ & $6.88^{\mathrm{ns}} \mathrm{A}$ & $6.31 \mathrm{aA}$ & 9.80 \\
\hline Cerrado & $3.05^{\mathrm{ns}}$ & $3.58^{\mathrm{ns}}$ & $4.83 b^{n s}$ & 29.14 \\
\hline $\mathrm{CV}(\%)$ & 15.14 & 25.94 & 3.40 & \\
\hline
\end{tabular}

Means followed by the same lowercase letter in the column and uppercase letter in the row do not differ in the Tukey test at a 5\% significance level. ${ }^{\text {ns: }}$ not significant to the $5 \% \mathrm{~F}$ test. CLIS: crop-livestock integration system; CV: coefficient of variation

Generally, an isotopic enrichment was observed in the pasture and CLIS areas, especially in LOM and POM, with greater $\delta^{15} \mathrm{~N}$ values for LOM. This greater isotopic enrichment may be a consequence of transformations of N-organic to N-mineral. Thus, as mineralization, nitrification, denitrification, and volatilization reactions occur, the remaining organic matter (POM) becomes enriched in ${ }^{15} \mathrm{~N}$ atoms (Bustamante et al., 2004; Hogberg, 1997). In the 0-5 cm layer of CLIS, the pattern regarding the enrichment of $\delta^{15} \mathrm{~N}$ (LOM < POM < Soil) could be due to more intense mineralization, nitrification, denitrification, and volatilization reactions occurring in this system after nitrogen fertilizers have been added and different plants (grasses and leguminous plants) influencing the nitrogen dynamics.

\section{Conclusions}

The Cerrado and CLIS areas show higher amounts of dry phytomass than the pasture. Plant residues from the pasture are richer in $\mathrm{P}, \mathrm{K}, \mathrm{Ca}, \mathrm{Mg}$, and $\mathrm{C}$ than CLIS, which is richer in $\mathrm{N}$.

The soil $\delta^{13} \mathrm{C}$ of pasture and CLIS areas showed a replacement of carbon from the Cerrado vegetation (typically $\mathrm{C}_{3}$ ) by new carbon from vegetation with $\mathrm{C}_{4}$ photosynthetic mechanisms (e.g., Brachiaria and corn).

The CLIS and pasture areas do not show differences in TOC and TN contents for the $0-10 \mathrm{~cm}$ layer. However, CLIS accumulates more TOC than pasture in the 10-20 cm layer. 
The particle size fractions of carbon (C-POM and C-MOM) and nitrogen (N-POM and N-MOM) did not differ between CLIS and pasture areas in the $0-5 \mathrm{~cm}$ layer. The CLIS presented lower CPOM and N-POM values than the pasture in the 5-10 cm layer. Nevertheless, CLIS provides higher C-MON and N-MOM values than pasture. The CLIS also provides higher N-LOM levels than pasture and Cerrado areas. The particle size fractionation of SOM into LOM, POM, and MOM was more efficient than TOC and TN $(0-10 \mathrm{~cm})$ for detecting variations among the different land uses evaluated in this study.

The $\delta^{13} \mathrm{C}$ of LOM is related to the most recent origin of carbon (related to current vegetation) in comparison to POM and soil. The $\delta^{15} \mathrm{~N}$ of POM and soil of the CLIS and pasture indicates greater mineralization of SOM and $\mathrm{N}$ assimilation by plants when compared with the Cerrado. Additionally, the $\delta^{15} \mathrm{~N}$ showed an isotopic enrichment in CLIS and pasture areas toward LOM in contrast to POM and soil.

\section{Acknowledgments}

This study was financed in part by the Coordenação de Aperfeiçoamento de Pessoal de Nível Superior - Brasil (CAPES) - Finance Code 001.

\section{References}

[1] Bayer, C., Mielniczuk, J., Amado, T.J.C., Martin-Neto, L., \& Fernandes S. V., Organic matter storage in a sandy clay loam Acrisol affected by tillage and cropping systems in southern Brazil. Soil and Tillage Research, 54(1-2), 2000, 101-109.

[2] Balesdent, J., \& Mariotti, A., Measurement of soil organic matter turnover using ${ }^{13} \mathrm{C}$ natural abundance. In: Boutton, T. W., Yamasaki, S. (Eds). Mass Spectrometry of Soil. New York: Marcel Dekker, 1996, p.83-111.

[3] Beutler, S.J., Pereira, M.G., Loss, A., Perin, A., \& Silva, C., Edaphic attributes of a crop-livestock integration system in the Cerrado biome. Revista Caatinga, 29(4), 2016, 892-900.

[4] Bremer, E., Ellert, B., \& Janzen, H., Total and light-fraction carbon dynamics during four decades after cropping changes. Soil Science Society America Journal, 59 (5), 1995, 1398-1403.

[5] Boer, C.A., Assis, R.L., Silva, G. P., Braz, A.J.B.P., Barroso A.L.L., \& Cargnelutti Filho A,. Ciclagem de nutrientes por plantas de cobertura na entressafra em um solo de cerrado. Pesquisa Agropecuária Brasileira, 42 (9), 2007, 1269-1276.

[6] Bustamante, M.M.C., Martinelli, L.A., Silva, D.A., Camargo, P.B., Klink, C.A., \& Domingues, T.F., ${ }^{15} \mathrm{~N}$ natural abundance in woody plants and soils of central brazilian savannas (Cerrado). Ecological Applications, 14(4), 2004, 200-213.

[7] Causarano, H.J., Franzluebbers, A.J., Shaw, J.N., Reeves, D.W., Raper R.L., \& Wood, C.W., Soil organic carbon fractions and aggregation in the Southern Piedmont and coastal plain. Soil Science Society of America Journal, 72(1), 2007, 221-230.

[8] Cambardella, C.A., \& Elliott, E.T., Particulate soil organic-matter changes across a grassland cultivation sequence. Soil Science Society of America Journal, 56(3), 1992, 777-783.

[9] Carvalho, J.L.N., Raucci, G.S., Cerri, C.E.P., Bernoux M., Feigl, B.J., Wruck, F.J., \& Cerri, C.C., Impact of pasture, agriculture and crop-livestock systems on soil C stocks in Brazil. Soil \& Tillage Research, 110(1), 2010, 175-186.

[10] Cook, R.L., Binkley, D., Mendes, J.C.T., \& Stape, J.L., Soil carbon stocks and forest biomass following conversion of pasture to broadleaf and conifer plantations in southeastern Brazil. Forest Ecology and Management, 324, 2014, 37-45. 
[11] Costa Junior, C., Piccolo, M.C., Siqueira Neto, M., Camargo, P.B., Cerri, C.C., \& Bernoux, M., Carbono total e ${ }^{13} \mathrm{C}$ em agregados do solo sob vegetação nativa e pastagem no bioma cerrado. Revista Brasileira de Ciência do Solo, 35(4), 2011, 1241-1252.

[12] Crusciol, C.A.C., Cottica, R.L., Lima, E.V., Andreotti, M., Moro, E., \& Marcon, E., Persistência de palhada e liberação de nutrientes do nabo forrageiro no plantio direto. Pesquisa Agropecuária Brasileira, 40(2), 2005, 161-168.

[13] Corazza, E.J., Silva, J.E.D., Resck, D.V.S., \& Gomes, A.C., Comportamento de diferentes sistemas de manejo como fonte ou depósito de carbono em relação à vegetação de Cerrado. Revista Brasileira de Ciência do Solo, 23(2), 1999, 425-432.

[14] Frazão, L.A., Santana, I.K.S., Campos, D.V.B., Feigl, B.J., \& Cerri, C.C., Estoques de carbono e nitrogênio e fração leve da matéria orgânica em Neossolo Quartzarênico sob uso agrícola. Pesquisa Agropecuária Brasileira, 45(1), 2010, 1198-1204.

[15] Golchin, A., Oades, J.M., Skjemstad, J.O., \& Clarke P., Soil structure and carbon cycling. Australian Journal of Soil Research, 32(5), 1994, 1043-1068.

[16] Giacomini, S.J., Aita, C., Vendruscolo, E.R.R.O, Cubilla, M., Nicoloso, R.S., \& Fries, M.R., Matéria Seca, relação $\mathrm{C} / \mathrm{N}$ e acúmulo de nitrogênio, fósforo e potássio em misturas de plantas de cobertura de solo. Revista Brasileira de Ciência do Solo, 27(2), 2003, 325-334.

[17] Gregorich, E.G., Carter, M.R., Angers, D.A., Monreal, C.M., \& Ellert, B.H., Towards a minimum data set to assess soil organic matter quality in agricultural soils. Canadian Journal of Soil Science, 74 (4), 1994, 367-385.

[18] Hentz, P., Carvalho, N.L., Luz, L.V., \& Barcellos, A.L., Ciclagem de nitrogênio em sistemas de integração lavoura-pecuária. Ciência e Natura, 36, 2014, 663-676.

[19] Högberg, P., 15N natural abundance in soil-plant system. New Phytologist, 137, 1997, 179-203.

[20] Koutika, L-S., Nolte, C., Yemefack, M., Ndango, R., Folefoc, D., \& Weise, S., Leguminous fallows improve soil quality un south-central Cameroon as evidenced by the particulate organic matter status. Geoderma, 125(3-4), 2005, 343-354.

[21] Lal, R., Soil carbon dynamics in cropland and rangeland. Environmental Pollution, 116(3), 2002, 353-362.

[22] Leite, L.F.C., Mendonça, E.S., Neves, J.C.L, Machado, P.L.O.A., \& Galvão, J.C.C., Estoques totais de carbono orgânico e seus compartimentos em Argissolo sob floresta e sob milho cultivado com adubação mineral e orgânica. Revista Brasileira de Ciência do Solo, 27(5), 2003, 821-832.

[23] Liebig, M.A., Tanaka, D.L., \& Wienhold, B.J., Tillage and cropping effects on soil quality indicators in the northern Great Plains. Soil Tillage Research, 78(2) 2004, 131-141.

[24] Loss, A., Pereira, M.G., Perin, A., Beutler, S.J., \& Anjos, L.H.C., Carbon and nitrogen content and stock in no-tillage and crop-livestock integration systems in the Cerrado of Goias State; Brazil. Journal of Agricultural Science, 4(8), 2012a, 96-105.

[25] Loss, A., Pereira, M.G., Perin, A., Beutler, S.J., \& Anjos, L.H.C., Carbon, nitrogen and natural abundance of $\delta 1^{3} \mathrm{C}$ e $\delta^{15} \mathrm{~N}$ of light-fraction organic matter under no-tillage and crop-livestock integration systems. Acta Scientiarum. Agronomy, 34(4), 2012b, 465-472.

[26] Loss, A., Pereira, M.G., Perin, A., Beutler, S.J., \& Anjos, L.H.C., Particulate organic matter in soil under different management systems in the Brazilian Cerrado. Soil Research, 50(8), 2012c, 685693.

[27] Loss, A., Pereira, M.G., Perin, A., Beutler, S.J., \& Anjos, L.H.C., Oxidizable carbon and humic substances in rotation systems with brachiaria/livestock and pearl millet/no livestock in the Brazilian Cerrado. Spanish Journal of Agricultural Research, 11(1), 2013, 217-231.

[28] Loss, A., Pereira, M.G., Perin, A., \& Anjos, L.H.C., Abundância natural de $\delta^{13} \mathrm{C}$ e $\delta^{15} \mathrm{~N}$ em sistemas de manejo conservacionista no cerrado. Bioscience Journal, 30(3), 2014, 604-615.

[29] Loss, A., Pereira, M. G., \& Torres, J. L. R., Carbono orgânico no solo sob sistemas conservacionistas no Cerrado. In: Amaral Sobrinho, N. M. B. do, Chagas, C. I., Zonta, E. (Org.). Impactos Ambientais Provenientes da Produção Agrícola: Experiências Argentinas e Brasileiras. Rio de Janeiro: Livre Expressão. 2016, pp. 259-282. 
[30] Lovato, T., Mielniczuk, J., Bayer, C., \& Vezzani, C., Adição de carbono e nitrogênio e sua relação com os estoques no solo e com o rendimento do milho em sistemas de manejo. Revista Brasileira de Ciência do Solo, 28(1), 2004, 175-187.

[31] Luce, M.S., Ziadi, N., Zebarth, B.J., Whalen, J.K., Grant, C.A., \& Gregorich, G., Particulate organic matter and soil mineral nitrogen concentrations are good predictors of the soil nitrogen supply to canola following legume and non-legume crops in western Canada. Journal Soil Science, 93(5), 2013, 607-20.

[32] Luce, M.S., Whalen, J.K., Ziadi, N., Zebarth, B.J., \& Chantigny, M., Labile organic nitrogen transformations in clay and sandy-loam soils amended with ${ }^{15} \mathrm{~N}$-labelled faba bean and wheat residues. Soil Biology Biochemistry, 68, 2014, 208-218.

[33] Lupwayi, N.Z., Clayton, G.W., O’Donovan, J.T., Harker, K.N., Turkington T.K., \& Soon, Y.K., Phosphorus release during decomposition of crop residues under conventional and zero tillage. Soil Tillage Research, 95, 2007, 231- 239.

[34] Maia, S.M.F., Carvalho, J.L.N., Cerri, C.E.P., Bernoux, N., Lal, R., Galdos, M.V., \& Cerri, C.C., Contrasting approaches for estimating soil carbon changes in Amazon and Cerrado biomes. Soil \& Tillage Research, 133, 2013, 75-84.

[35] Marin-Spiotta, E., Silver, W.L., Swanston, C.W., \& Ostertag, R,. Soil organic matter dynamics during 80 years of reforestation of tropical pastures. Global Change Biology. 15(6), 2009, 15841597.

[36] Menezes, C.E.G., Pereira, M.G., Correia, M.E.F., Anjos, L.H.C., Paula, R.R., \& Souza, M.E., Aporte e decomposição da serapilheira e produção de biomassa radicular em florestas com diferentes estágios sucessionais em pinheiral, RJ. Ciência Florestal, 20(3), 2010, 439-452.

[37] Pereira, M.G., Loss, A., Beutler, S.J., \& Torres, J.L.R., Carbono, matéria orgânica leve e fósforo remanescente em diferentes sistemas de manejo do solo. Pesquisa Agropecuária Brasileira, 45(5), 2010, 508-514.

[38] Pereira, C.A., Silva, M.R.S.S., Quirino, B.F., Bustamante, C.M.M., \& Krüger, R.H., Microbial Diversity in Cerrado Biome (Neotropical Savanna) Soils. Plos One. 11(2), 2016, e0148785.

[39] Pessenda, L.C.R., Avarena, R., Melfi, A.J., Telles, E.C.C., Boulet, R., \& Valencia, E.P.E., The use of carbon isotopes $(13 \mathrm{C}, 14 \mathrm{C})$ in soil to evaluate vegetation changes during the Holocene in Central Brazil. Radiocarbon, 38(2), 1996, 191201.

[40] Rangel, O.J.P., \& Silva, C.A., Estoques de carbono e nitrogênio e frações orgânicas de Latossolo submetido a diferentes sistemas de uso e manejo. Revista Brasileira de Ciência do Solo, 3(6), 2007, 1609-1623.

[41] Ratter, J.A., Bridgewater, S., \& Ribeiro, J.F., Analysis of the floristic composition of the brazilian cerrado vegetation III: comparison of the woody vegetation of 376 areas. Edinburgh Journal of Botany, 60 (1), 2003, 57-109.

[42] Roscoe, R., Buurman, P., Velthorst, E.J., \& Pereira, J.A.A., Effects of fire on soil organic matter in a "Cerrado sensu-stricto" from Southeast Brazil as revealed by changes in $\delta 13 \mathrm{C}$. Geoderma, 95(1-2), 2000, 141160.

[43] Salton, J.C., Mielniczuk, J., Bayer, C., Fabrício, A.C., Macedo, M.C.M., \& Broch, D.L., Teor e dinâmica do carbono no solo em sistemas de integração lavoura-pecuária. Pesquisa Agropecuária Brasileira, 46(10), 2011, 1349-1356.

[44] Sant-anna, S.A.C., Jantalia, C.P., Sá, J.M., Vilela, L., Marchão, R.L., \& Alves, B.J. R., Changes in soil organic carbon during 22 years of pastures, cropping or integrated crop/livestock systems in the Brazilian Cerrado. Nutrient Cycling in Agroecosystems, 108(1), 2017, 101-120.

[45] Sano, E. E., Rosa, R., Brito, J. L., \& Ferreira, L.G., Mapeamento semidetalhado do uso da terra do bioma Cerrado. Pesquisa Agropecuária Brasileira, 43(1), 2008, 153-156.

[46] Silva, J.E., Resck, D.V.S, Corazza, E.J., \& Vivaldi, L.,.Carbon storage under cultivated pastures in a clayey Oxisol in the Cerrado Region, Brazil. Agriculture, Ecossystem and Environment, 103 (2), 2004, 357-363. 
[47] Smith, B.N., \& Epstein, S., Two categories of 13C/12C ratios for higher plants. Plant Physiology, 47, 1971, 380-384.

[48] Tedesco, M.J., Gianello, C., Bissani, C.A., Bohnen, H., \& Volkweiss, S.J., Análises de solo, plantas e outros materiais. Universidade Federal do Rio Grande do Sul, Porto Alegre, Boletim Técnico. 1995, 174p.

[49] Tivet, F., Sá, J.C.M, Lal, R., Briedis, C., Borszowskei, P.R., \& Santos, J.B., Aggregate C depletion by plowing and its restoration by diverse biomass-C inputs under no-till in sub-tropical and tropical regions of Brazil. Soil and Tillage Research, 126, 2013, 203-218.

[50] Torres, J.L.R, Pereira, M.G., \& Fabian, A.J., Produção de fitomassa por plantas de cobertura e mineralização de seus resíduos em plantio direto. Pesquisa Agropecuária Brasileira, 43(3), 2008, 421-428.

\footnotetext{
*Corresponding author.

E-mail address: arcangelo.loss@ufsc.br/arcangeoloss@yahoo.com.br
} 